\title{
Peran Elit Masyarakat: Studi Kebertahanan Adat Istiadat di Kampung Adat Urug Bogor
}

Asep Dewantara

\begin{abstract}
Abstrak
Tulisan ini merupakan penelitian studi lapangan dengan Judul Peran Elit Masyarakat: Studi Kebertahanan Adat Istiadat Di Kampung Adat Urug Bogor ini bertujuan pertama, menguji teori Ajip Rosidi mengenai Perubahan Sosial Budaya melalui data lapangan atau secara empiris. Kedua untuk mengungkapkan nilainilai budaya dalam adat istiadat atau kearifan lokal di Kampung Adat Urug dan menjelaskan peran Ketua Adatnya sebagai elit masyarakat dalam menjaga keberlangsungan adat istiadat tersebut. Penelitian ini bersifat deskriptif-kualitatif dengan menggunakan pendekatan Antropologis, Sosiologis dan Hermeunitik. Sementara Subjek kajiannya adalah masyarakat kontemporer di Kampung Adat Urug, Desa Kiarapandak, Kecamatan Sukajaya kabupaten Bogor, terutama Ketua Adat yang berjumlah tiga orang dan sebagian warga sebagai informan.
\end{abstract}

Kata kunci: Elit Masyarakat, Kebertahanan, Adat-istiadat, Kampung Adat Urug

\begin{abstract}
Thesis research field studies with title Role Of Elite Society: Studies Of Viability Customs In Kampung Adat Urug Bogor aims first to test the theory of Ajip Rosidi on social-cultural change through field data or empirically. Second to express cultural values in customs or local wisdom in Kampung Adat Urug Bogor and explains the role of chairman of the customary as an elite society in maintaining the continuity of traition. This research is a descriptive-qualitative anthropological, sociological and hermeunitik. While the subject of study is of contemporary society in Kampung Adat Urug, Kiarapandak village, Sukajaya District, Bogor regency, especially indigenous Chairman of three people and some residents as informants.
\end{abstract}

Keywords: Elite Society, Viability, Customs/Local Wisdom, Kampung Adat Urug Bogor. 


\section{A. Pendahuluan}

Kajian ini ingin melihat masyarakat Sunda Bogor sebagai sebuah komunitas yang mengalami perubahan seiring dengan kemajuan zaman. Kesimpulan hasil studi Ajip Rosidi menyebutkan bahwa seiring dengan perubahan zaman akan terjadi pergeseran atau pengikisan adat istiadat dan tradisisi. ${ }^{1}$ Akan tetapi Kenyataan lapangan, penulis menemukan bahwa pada komunitas masyarakat Sunda Bogor dalam praktek kehidupan sehariharinya masih berpedoman dan berpegang teguh pada adat istiadat dan tradisi setempat. ${ }^{2}$ Persoalannya mengapa pada komunitas masyarakat Sunda Bogor adat istiadat dan tradisinya bisa bertahan. Menurut asumsi penulis bahwa kebertahanan adat istiadat dan tradisi ini tidak lepas dari peran sesepuh sebagai elit masyarakat dalam menjaga adat istidat dan tradisi tersebut.

Masyarakat Sunda adalah salah satu kelompok etnis atau suku bangsa di

\footnotetext{
${ }^{1}$ Ajip Rosidi, Manusia Sunda (Jakarta: Inti Idayu Press, 1984), h. 13. Lihat pula Ajip Roisdi, Mencari Sosok Manusia Sunda (Jakarta: Pustaka Jaya, 2010), h. 51-66.

${ }^{2}$ Survei penulis misalnya pada tanggal 7-8 April 2012 di Kampung adat Urug, Desa Kiara Pandak, Kecamatan Sukajaya, Kabupaten Bogor. Dalam praktek kesehariannya mereka masih memegang teguh adat istiadat dari leluhurnya. Di sini Adat diartikan sebagai salah satu wujud kebudayaan yang bersifat abstrak, biasaya berupa gagasan yang dituangkan melalui lisan atau dalam bentuk tulisan. Adat juga berfungsi untuk mengatur, mengendalikan dan memberi arah kepada kelakuan dan perbuatan manusia dalam masyarakat. Lihat Koentjaraningrat, Kebudayaaan mentalitas dan pembangunan (Jakarta: PT Gramedia, 1974), h. 5. Demikianlah adat yang masih bertahan dalam komunitas masyarakat Sunda di kampung Adat Urug, Bogor misalnya larangan untuk berlebihan dalam segala sesuatu, seperti dalam sikap dan tindakan jangan mengambil yang bukan hak kita, harus menghormati orang tua, guru dan pemerintah yang baik, harus bisa memelihara indera atau alat-alat tubuh dan adat istiadat lainnya.
}

Indonesia yang mendiami sebelah Barat pulau Jawa, yaitu daerah-daerah yang sekarang dikenal dengan nama Bandung, Garut, Sukabumi, Cianjur, Tasikmalaya, Sumedang, Ciamis, Kuningan, Cirebon, Banten yang sekarang menjadi provinsi sendiri, ${ }^{3}$ Bekasi, Karawang dan Bogor. Bahasa dan penggunaan nama diri menjadi salah satu identitas kesundaan mereka yang paling menonjol. Sedang dalam perspektif antropologi budaya, suku bangsa Sunda adalah orang-orang yang secara turun-temurun menggunakan bahasa Sunda beserta dialeknya sebagai bahasa ibu dalam kehidupan sehari-hari dan berasal atau bertempat tinggal di Jawa Barat. Demikianlah, daerah Jawa Barat dikenal juga dengan istilah Tanah Pasundan atau Tatar Sunda yang secara kultural (penggunaan bahasa), masih terlihat dipakai di daerah Cilosari dan Citanduy yang menjadi batas wilayah Jawa Barat dan Jawa Tengah. ${ }^{4}$

Dalam konteks pemikiran di atas sering kali sebutan Urang Sunda (Orang Sunda) adalah mereka yang mengaku dirinya dan diakui oleh orang lain sebagai orang Sunda. Dengan demikian sekurang-kurangnya ada dua kriteria bahwa seseorang atau sekelompok orang dikatakan sebagai orang Sunda. Pertama, aspek genetik (keturunan) atau hubungan darah. Seseorang atau sekelompok orang bisa disebut orang Sunda bila orang tuanya, baik dari pihak ayah atau pihak ibu maupun keduanya adalah orang Sunda dan di manapun orang itu dilahirkan, dibesarkan dan berada. Kedua, aspek lingkungan sosial budaya. Mereka akan disebut orang Sunda jika lahir, tinggal dan dibesarkan di daerah Sunda serta menggunakan dan menghayati norma-

\footnotetext{
${ }^{3}$ Banten sekarang menjadi provinsi sendiri sejak tahun 2000, lihat Nina Herlina Lubis, Banten Dalam Pergumulan Sejarah: Sultan, Ulama, dan Jawara (Jakarta: LP3S, 2003), h.233-237.

${ }^{4}$ Koentjaraningrat, Manusia dan kebudayaan Indonesia (Jakarta: Djambatan, 1971), h. 300.
} 
norma dan nilai-nilai budaya Sunda walaupun kedua orang tuanya atau leluhurnya bukan orang Sunda. ${ }^{5}$

Berdasarkan uraian di atas maka bisa dirumuskan bahwa orang Sunda mempunyai ciri-ciri di antaranya lahir dan besar atau berasal dari Tanah Pasundan, bisa berbahasa Sunda dan menggunakan nama diri khas Sunda ${ }^{6}$ serta menghayati norma-norma dan nilai-nilai budaya Sunda. Selain itu, ciri-ciri manusia Sunda bisa dilihat juga dari pandangan hidup mereka yang tergambar dalam beberapa peribahasa atau ungkapan. Misalnya Orang Sunda sangat terikat dengan tanah kelahirannya, sejauh apa pun dia pergi atau merantau pasti akan kembali ke tempat dia berasal seperti dalam peribahasa "Bengkung ngariung bongkok ngaronyok jeung dulur di bali geusan ngajadi" (meskipun "bungkuk" tetapi bersama saudara di kampung sendiri) ${ }^{7}$.

Peribahasa lainnya yang menandakan sifat orang Sunda, yaitu mengenai hubungan persaudaraan atau hubungan darah yang diketahui dalam beberapa peribahasa di bawah ini antara lain; "Buruk-buruk papan jati" (walaupun buruk seperti apa pun jika dia saudara kita, akuilah sebagai saudara), "Ari salaki atawa pamajikan mah aya urutna, tapi ari dulur mah moal aya urutna" (boleh dikatakan suami atau istri itu ada bekasnya, tetapi yang namanya saudara itu tidak akan pernah ada bekasnya).

${ }^{5}$ Edi Suhardi Ekadjati, Kebudayaan Sunda Jilid 1 (Jakarta: Pustaka Jaya, 1995), h. 7.

${ }^{6}$ Di zaman modern seperti sekarang ini, tidak sedikit memang orang Sunda yang sudah tidak menggunakan nama khas Sunda. Dan sebagai catatan, tidak semua orang yang bisa berbahasa Sunda disebut orang Sunda, karena bisa saja orang tersebut bukan berasal dari Sunda dan tidak memiliki garis keturunan sunda sama sekali serta tidak menghayati nilai dan norma budaya Sunda, karena bahasa itu bisa dipelajari.

${ }^{7}$ Ajip Rosidi, Mencari Sosok Manusia Sunda, h. 216-217.
Dalam lingkungan masyarakat Sunda ada peribahasa yang menggambarkan hal-hal yang negatif, sehingga maksudnya mengingatkan agar orang Sunda menghindari hal-hal itu, seperti tergambar dalam beberapa peribahasa berikut; "Asa Aing uyah Kidul" (angkuh, sombong, merasa paling hebat, seperti garam dari laut Selatan yang lebih asin dari garam asal laut lain), "Nyieun pucuk ti Girang" (membuat pangkal permasalahan), "Kandel kulit beungeut" (tidak punya malu), "Mipit teu amit ngala teu mènta" (mengambil sesuatu atau memetik hasil tanaman tanpa meminta izin dahulu kepada yang punya). Selain itu ada pula peribahasa yang menerangkan kebaikan sehingga orang Sunda dianjurkan untuk melakukannya, seperti peribahasa "Ka cai jadi saleuwi, ka darat jadi salogak, sareundeuk saigel, sabobot sapihandèan, sabata sarimbagan" (selalu hidup rukun tidak pernah bertengkar hanya karena silang pendapat), "Cikaracak ninggang batu, laun-laun jadi legok" (segala sesuatu jika dikerjakan dengan sabar dan tekun, pasti akan ada hasilnya), "Ngukur ka kujur nimbang ka awak" (harus tahu diri, sadar diri, jangan melakukan halhal yang di luar kemampuan kita). Dalam konteks ini Ajip Rosidi menegaskan, bahwa peribahasa itu mencerminkan bangsa yang memilikinya atau menunjukkan kepribadian manusianya. ${ }^{8}$

Nilai-nilai yang terkandung dalam peribahasa tersebut dapat diidentikkan dengan ciri-ciri manusia Sunda sebagaimana yang penulis katakan di atas, terdapat dalam naskah Sunda lama yaitu naskah Sanghyang Siksakandang Karesian (ajaran tentang hidup arif berdasarkan darma $)^{9}$,

\footnotetext{
${ }^{8}$ Ajip Rosidi, Mencari Sosok Manusia Sunda, h. 44.

${ }^{9}$ Saleh Danasasmita, dkk., Sewaka Darma, Sanghyang Siksakandang Karesian, Amanat Galunggung: Transkripsi dan Terjemahan
} 
termasuk adat istiadat dan tradisi yang bertahan pada komunitas masyarakat Sunda di Kampung Adat Urug, Desa Kiara Pandak, Kecamatan Sukajaya, Kabupaten Bogor. Dalam kolofonnya ${ }^{10}$ diketahui bahwa naskah ini selesai ditulis pada tahun 1440 saka atau 1518 M. Jadi, naskah Sanghyang Siksakandang Karesian ini lahir pada masa kejayaan Kerajaan Sunda Pakuan Pajajaran, Bogor (1482-1579 M). ${ }^{11}$

Dengan demikian Naskah Sanghyang Siksakandang Karesian yang disebut juga dengan Talatah Sang Sadu (amanat sang Budiman) berisi ajaran moral, etika dan keagamaan, bagaimana cara bergaul dengan sesama, bersikap kepada Raja, mencapai kesejahteraan hidup dan lain sebagainya. $^{12}$ Untuk mencapai kesejahteraan hidup, dalam naskah ini dituliskan bahwa orang Sunda di antaranya harus bisa mengendalikan sepuluh inderanya (Dasa Kreta), harus berani dan mau menerima kritik (Panca Parisuda), beramal baik serta menjalankan darmanya masing-masing (Tapa di Nagara), jangan berlebihan dalam segala hal seperti dalam sikap dan tindakan, dilarang untuk mengambil sesuatu yang bukan haknya dan nasehat lainnya. Dalam hal ini Budayawan Ajip Rosidi merumuskan ajaran dalam naskah SSKK menjadi

(Bandung: proyek pengkajian dan penelitian kebudayaan Sunda (Sundanologi), 1987), h. 6 dan 94-118.

${ }^{10}$ Kolofon adalah bagian dari naskah lama, berupa kalimat atau paragraf yang terletak di awal atau di akhir naskah yang memberikan informasi mengenai identitas naskah, seperti waktu penulisan naskah (tarikh), tokoh yang menulis naskah dan tempat penulisan naskah. Lihat Henri Chambert Loir, "kolofon Melayu", penerjemah Arif Bagus Prastyo. Indonesia and the Malay World, vol.34, no. 100, November 2006, h. 1-3.

${ }^{11}$ Uraian lebih mendalam tentang hal ini akan penulis jelaskan dalam bab ke-3.

${ }^{12}$ Untuk selanjutnya penulis akan menyingkat penulisan Naskah Sanghyang Siksakandang Karesian menjadi SSKK. tiga poin, 1. Sebagai pedoman dalam menjalani hidup, 2. Sebagai kontrol sosial terhadap kehendak dan nafsu yang timbul pada diri seseorang, 3 . Sebagai pembentuk suasana dalam masyarakat tempat seseorang lahir, tumbuh dan dibesarkan yang secara tidak sadar meresap ke dalam diri semua anggota masyarakat. ${ }^{13}$

Dari uraian di atas, ada beberapa hal yang menurut penulis menarik untuk diteliti, pertama nilai-nilai yang terkandung dalam naskah SSKK ini ternyata masih dipertahankan (menjadi tradisi) oleh masyarakat Kampung Adat Urug, Bogor. Persoalannya mengapa adat istiadat dan tradisi tersebut masih bertahan pada masyarakat Kampung Adat Urug, yang menurut asumsi penulis terletak pada peran Sesepuh masyarakatnya. Singkatnya penelitian ini ingin menguji teori Ajip Rosidi di atas terkait dengan perubahan nilai budaya masyarakat Sunda. selain itu, penulis juga ingin menjelaskan adat istiadat di kampung Adat Urug dan bagaimana peran sesepuh dalam hal ini Ketua Adat untuk menjaga dan melestarikan adat istiadat tersebut.

\section{Tinjauan Pustaka}

Mengenai Kampung Adat Urug, penulis temukan pertama dalam buku yang berjudul Kasepuhan yang Tumbuh di atas yang Luruh "Pengelolaan Lingkungan Secara Tradisional di Kawasan Gunung Halimun Jawa Barat" yang ditulis oleh Kusnaka Adimiharja. Kedua dalam buku Sanghyang Raja Uyeg "dari sakral ke profan" karya Arthur S Nalan. Dalam kedua buku ini kampung Adat Urug ditulis sedikit, sebagai salah satu Kampung Adat atau Kasepuhan. Seperti Kasepuhan lainnya di Jawa barat, Kasepuhan Urug mempunyai

\footnotetext{
${ }^{13}$ Ajip Rosidi, Mencari Sosok Manusia Sunda, h. 59.
} 
hubungan dengan kerajaan Pajajaran (1482-1579 M). Buku yang pertama objek kajiannya difokuskan pada Kasepuhan Bungur di wilayah Sukabumi dalam pengelolaan lingkungan secara tradisional. Sementara buku Kedua membahas kesenian teater rakyat yang berasal dari masyarakat Kasepuhan kaitannya dalam penanaman padi dan cerita Dewi Sri. Adapun mengenai studi tentang kepemimpinan tradisional pada suatu Kampung Adat, penulis menemukan judul sebuah buku "Kasepuhan Sirnaresmi: $\quad$ Studi Tentang Kepemimpinan Tradisional di Sukabumi Selatan" yang ditulis oleh Yudistira Garna tahun 1973, dari judul itu bisa diketahui bahwa objek kajiannya berada di Kasepuhan Sirnaresmi Sukabumi.

Dari keterangan yang didapat penulis ketika ke lokasi penelitian, memang sudah ada beberapa penelitian mengenai Kampung Adat Urug, tapi kebanyakkan penelitian itu mengenai masalah pertanian khususnya tanaman padi, adapun penelitian mengenai adat istiadat dan tradisi setempat hanya terbatas misalnya pada satu kegiatan seperti Seren Taun (syukuran hasil panen), bukan mengenai adat istiadat yang dimaksud penulis, Yaitu talèk, pamali, cegahan atau larangan yang menjadi aturan dan pedoman hidup warga Urug.

Setelah coba mencari di Media Online (Internet) penulis menemukan skripsi dalam format PDF yang menjadikan Kampung Adat Urug sebagai objek penelitian. Skripsi tersebut ditulis oleh Cefti Lia Permatasari dari Institut Pertanian Bogor (IPB), Departemen Ilmu Keluarga dan Konsumen, Fakultas Ekologi Manusia dengan judul Nilai Budaya, Pengasuhan PenerimaanPenolakan, dan Perkembangan Sosial Anak Usia 3-5 Tahun pada Keluarga Kampung Adat Urug Bogor.Isi pokok
Skripsi tersebut yaitu pembahasan mengenai beberapa nilai budaya (larangan atau cegahan) yang berkaitan dengan pola pengasuhan anak usia 3-5 tahun, hubungan orang tua dan anak, dan pengasuhan berdasarkan gender terkait pembagian tugas pada anak, yang dijadikan responden dalam penelitian ini adalah kaum ibu dan anak-anak usia 3-5 Tahun.

Sementara itu pokok kajian penulis dalam penelitian ini pertama adalah adat istiadat atau kearifan lokal berupa nilai-nilai budaya yang disebut dengan talèk (aturan), pamali (larangan, cegahan dan anjuran) yang berkaitan dengan moral dan etika, adab sopansantun dan tata kelakuan bermasyarakat. Kedua, mengenai peran Ketua Adatnya sebagai bagian dari elit masyarakat dalam menjaga keberlangsungan adat istiadat tersebut. Dengan demikian studi ini dapat melengkapi penelitian-penelitian sebelumnya mengenai adat istiadat dan tradisi yang menjadi pandangan hidup bermasyarakat serta kepemimpinan tradisional pada sebuah Kampung Adat.

\section{Tujuan Penelitian}

Berdasarkan permasalahan di atas, tujuan penelitian ini adalah sebagai berikut:

1. Untuk Menguji teori Ajip Rosidi tentang perubahan sosial budaya melalui data lapangan.

2. Untuk mengungkapkan nilainilai dalam adat istiadat di kampung adat Urug.

3. Untuk menjelaskan upaya-upaya sesepuh masyarakat Kampung Adat Urug, Bogor dalam memelihara adat istiadat dan tradisi yang ada.

\section{Metode Penelitian}

1. Pendekatan Penelitian 
Dalam penelitian ini, penulis menggunakan pendekatan Antropologi, Sosiologi, dan Hermeneutik.

2. Jenis dan Sumber Data

a. Jenis Data

Dalam penelitian ini jenis data yang dikumpulkan adalah 1. Deskripsi sosial, budaya dan ekonomi masyarakat Sunda Kampung Adat Urug Bogor, 2. adat istiadat dan tradisi di Kampung Adat Urug Bogor, 3. konsep Sesepuh dan upayaupaya yang dilakukan dalam konteks kebertahanan adat istiadat dan tradisi masyarakat.

\section{b. Sumber Data}

\section{b.1. Sumber Data Primer}

Sumber data Primer dalam penelitian ini antara lain, wawancara, dokumen berupa naskah-naskah Sunda tua dan pengamatan langsung. Jadi Deskripsi sosial, budaya dan ekonomi masyarakat Kampung Adat Urug, Bogor, kemudian adat istiadat dan tradisi masyarakat Kampung Adat Urug serta upaya-upaya para sesepuh dalam menjaga adat istiadat dan tradisi tersebut datanya bersumber dari pengamatan langsung di Kampung Adat Urug dan wawancara kepada elit masyarakat seperti sesepuh Kampung Adat (Abah Ukat, Abah Amat dan Abah Kayod) pengurus desa (Bapa Ade Eka Komara selaku Sekretaris Desa Kiara Pandak), dan sebagian warga.

\section{b.2. Sumber Data Sekunder}

Adapun sumber data sekunder antara lain; pandangan, tulisan orang lain yang memiliki relevansi dengan sumber data primer yang penulis dapatkan dari berbagai laporan penelitian, jurnal, majalah, makalah, buku, media cetak dan elektronik.

3. Metode pengumpulan data

Cakupan riset meliputi studi kepustakaan dan lapangan. Studi kepustakaan, yaitu menelusuri sumber data dari berbagai bacaan, baik yang bersifat primer maupun sekunder yang didapat dari perpustakaan umum maupun pribadi (private library), misalnya buku-buku, dokumen, koran, majalah, catatan pribadi, monograf, catatan kisah sejarah, hasil penelitian, yang dipandang masih berkaitan dengan topik permasalahan. ${ }^{14}$

Adapun studi lapangan, yaitu kegiatan observasi dan wawancara langsung kepada sumber informasi yang dapat memberikan keterangan sesuai dengan subyek kajian. ${ }^{15}$

4. Analisis Data

Data yang terkumpul kemudian diklasifikasikan atau dikategorikan untuk Selanjutnya, diseleksi berdasarkan relevansi dengan subyek kajian. Tahap kategorisasi bertujuan mengelompokkan setiap data ke dalam unit-unit analisis berdasarkan kesesuaian antara satu tema dengan tema lainnya sehingga menggambarkan keseluruhan analisis yang utuh. Kemudian dilakukan analisis sistemik untuk mengungkap bertahannya adat istiadat dan tradisi (nilai-nilai) pada masyarakat Sunda di Kampung Adat Urug, Bogor. Tujuannya untuk mencari keterkaitan antar berbagai komponen dan konsep sehingga membentuk satu kesatuan sistem yang kompleks agar dapat memahami hakikat kebertahanan adat Istiadat dan tradsi pada masayarakat Sunda Bogor di Kampung Adat Urug. Jadi, penelitian ini bersifat deskriptif-kualitatif. ${ }^{16}$

5. Langkah penelitian

Secara umum, metode penulisan sejarah ini sendiri dilakukan dengan

${ }^{14}$ Kartodirdjo, "Metode Pengunaan Bahan Dokumen", dalam Koentjaraningrat, ed., Metode-Metode Penelitian Masyarakat (Jakarta: Gramedia, 1979), h. 61-92, 87.

${ }^{15}$ Koentjaraningrat, "Metode Wawancara" dalam Koentjaraningrat, ed., Metode-Metode Penelitian Masyarakat, 162-196. Bachtiar, "Pengamatan Sebagai Suatu Metode Penelitian", dalam Koentjaraningrat, ed., Metode-Metode Penelitian Masyarakat, h. 137161.

${ }^{16}$ Sanafiah Faisal, ed., Metodologi Penelitian Kualitatif (Surabaya: Usaha Nasional, 1987), h. 63. 
empat langkah, yaitu heuristik, kritik, interpretasi, dan historiografi. ${ }^{17}$ Heuristik adalah pengumpulan dan penelusuran sumber data melalui pelacakan atas berbagai dokumen, serta wawancara dengan para tokoh masyarakat Kampung Adat Urug. Adapun penelusuran sumber data primer dan sekunder dilakukan ke perpustakaan, baik umum, seperti Prpustakaan utama dan Fakultas, UIN Syarif Hidayatullah Jakarta, Perpustakaan LIPI, Perpustakaan Nasional RI, Perpustakaan daerah Provinsi Jawa Barat, Perpustakaan Museum Sri Baduga, Perpustakaan Universitas Padjajaran dan perpustakaan koleksi pribadi yang ada kaitannya dengan pokok bahasan, di antaranya Perpustakaan Drs. Saidun Derani, MA, perpustakaan pribadi Uwa Mamat Sasmita (Rumah Baca Buku Sunda) di perumahan Margawangi, Jl margawangi VII, No. 5, Margacinta, Bandung.

Selain itu karena riset ini juga lapangan, penulis memilih responden, menyeleksi berdasarkan jenis data yang dibutuhkan meliputi kategori tokoh masyarakat di Kampung Adat Urug, Bogor.

Terakhir menguji fakta dan data sejarah yang sudah dikumpulkan. Kritik eksteren dilakukan untuk menguji keaslian atau otentisitas sebuah sumber sejarah yang asli. Sedang kritik interen dilakukan untuk menguji validitas data sejarah. Langkah interpretasi adalah upaya menafsirkan data berdasarkan perspektif tertentu sehingga fakta itu menjadi struktur yang logis. Langkah historiografi adalah menuliskan hasil

\footnotetext{
${ }^{17}$ Hariyono, Mempelajari Sejarah Secara Efektif, (Yogyakarta: Pustaka Jaya, 1995, h. 109-110. Dudung Abdurrahman, Metode Penelitian Sejarah, h. 44. Louis Gottschalk, Understanding History: A Primer of Historical Method (Jakarta: Yayasan Penerbit UI, 1975), h. 18-19.
}

penafsiran menjadi sebuah kisah sejarah yang utuh versi penulis.

\section{B. Pembahasan}

\section{Sekilas Kampung Adat Urug}

\section{Letak Geografis dan Sejarah Kampung Adat Urug}

Secara administratif, kampung Adat Urug masuk dalam wilayah pemerintahan Desa Kiarapandak Kecamatan Sukajaya Kabupaten Bogor. Jarak tempuh Kampung Adat Urug dari Ibukota provinsi Jawa Barat sekitar 165 $\mathrm{Km}$ ke arah Barat, sementara dari Ibukota Kabupaten Bogor kurang lebih $48 \mathrm{Km}$. Jika dari kecamatan Sukajaya, hanya berjarak $6 \mathrm{Km}$, sedangkan dari kantor Desa Kiarapandak lebih dekat lagi, hanya $1,2 \mathrm{Km}^{18}$.

Kampung Adat Urug yang berada di wilayah desa Kiarapandak ini dalam bahasa setempat sering disebut Lembur Urug (Kampung Urug), terletak pada kordinat $6^{\circ} 34^{\prime} 42^{\prime \prime}$ Lintang Selatan, dan $106^{\circ} 29^{\prime} \quad 28^{\prime \prime}$ Bujur Timur, ${ }^{19}$ dengan luas wilayah $10 \mathrm{Ha}^{20}$ Kampung Adat Urug berbatasan dengan Desa Nanggung kecamatan Nanggung di sebelah Timur dengan Sungai Cidurian sebagai pembatas langsung. Di sebelah Barat, Kampung Adat Urug berbatasan dengan Desa Cisarua dan Desa Pasir Madang kecamatan Sukajaya. Sementara di sebelah Selatan, Kampung Adat Urug berbatasan dengan Desa Kiarasari kecamatan Sukajaya dan Desa Curug Bitung Kecamatan Nanggung. Sedangkan di sebelah Utara, Kampung Adat Urug berbatasan dengan

\footnotetext{
${ }^{18}$ Dinas kebudayaan dan pariwisata Kabupaten Bogor (www.disparbudjabarprov.go.id), akses 8 Oktober 2012.

${ }^{19}$ Dinas kebudayaan dan pariwisata Kabupaten Bogor (www.disparbudjabarprov.go.id), akses 8 Oktober 2012.

${ }^{20}$ Monografi Kampung Addat Urug Desa Kiarapandak Kecamatan Sukajaya, Bogor (Kantor Desa Kiarapandak).
} 
Desa Sukajaya dan Desa Harkatjaya kecamatan Sukajaya. $^{21}$

Mengenai sejarah atau asal-usul keberadaan kampung adat di Jawa Barat, tidak akan pernah lepas dari Kerajaan Sunda Pakuan Pajajaran (1482-1579) di Bogor. ${ }^{22}$ dari hasil penelitian penulis di kampung Adat Urug, penulis mendapatkan keterangan yang bisa digolongkan ke dalam sejarah lisan atau oral history bahwa Kampung Adat Urug memang memiliki hubugan yang erat dangan kerajaan Sunda Pakuan Pajajaran. ${ }^{23}$ Sebagian keterangan ada yang sesuai dengan buku-buku akademis atau karya-karya ilmiah di seputar sejarah Jawa barat yang disusun oleh para ahli sejarah, sebagian keterangan lagi penulis sebut sebagai legenda warga kasepuhan ${ }^{24}$ yang mungkin oleh sebagian orang diartikan sebagai mitos.

Menurut Abah Ukat, sejarah Kampung Adat Urug itu bisa dimulai di awal atau di akhir. Jika dari awal, yaitu awal berdirinya Pajajaran Bogor, jika di akhir, tilemna, ngahyang (menghilangnya) Prabu Siliwangi di Bogor sampai muncul di Kampung Adat Urug yang memang sudah direncanakan oleh Prabu Siliwangi sebagai tempat terakhirnya. Sebelum muncul di Kampung Adat Urug, Prabu Siliwangi menghilang dan muncul di beberapa daerah. Berikut ini adalah urutan daerah di mana Prabu Siliwangi menghilang dan muncul mulai dari Pajajaran Bogor---Panyaungan (jalan cagak (bercabang) yang ke arah Pongkor dan Cigudeg)---Parung Sapi (arah Jasinga)---Sajra (Kabupaten

\footnotetext{
${ }^{21}$ Peta lokasi Kampung Adat Urug Desa Kiarapandak kecamatan Sukajaya Kabupaten Bogor (Kantor Desa Kiarapandak).

${ }^{22}$ Kusnaka Adimihardja, Kasepuhan yang Tumbuh di atas yang Luruh, h. 15-23.

${ }^{23}$ Wawancara Pribadi dengan Abah Ukat (Ketua Adat Urug Lebak), Bogor, 22 April 2012.

${ }^{24}$ Kusnaka Adimihardja, Kasepuhan yang Tumbuh di atas yang Luruh, h. 15.
}

Lebak, Banten)---Seuni (kabupaten Pandeglang, Banten)---Lebak Binong (Cibaliung, Banten Kidul)---Cipatat--Kampung Urug. ${ }^{25}$ jadi Kampung Adat Urug adalah tempat pulang Prabu Siliwangi, "tidak akan ada tempat ini jika yang di Bogor masih ada. ${ }^{26}$ Meghilangnya Prabu Siliwangi mulai dari Pajajaran sampai terakhir di Kampung Adat Urug karena tidak mau masuk agama Islam yang pada saat itu dibawa oleh Raden Kian Santang, anaknya sendiri". ${ }^{27}$

"Jadi Kampung Urug ini adalah tempat pulang Prabu Siliwangi, Abah tidak mengaku ini tempat Abah, luas seperti ini, apa lagi Abah hanya tinggal berdua dengan Emak". Lanjut menurut penuturan Abah Ukat, Prabu Siliwangi setibanya di Kampung Urug mempunyai tiga orang Putra. yang pertama laki-laki, yang ke dua perempuan dan yang ketiga laki-laki. Prabu Siliwangi memberikan mandat atau amanatnya untuk mewarisi, menjaga Kampung Adat Urug kepada putranya yang ketiga. Makam dari putra yang ketiga tersebut berada di tepi kali Cidurian. $^{28}$ yang kedua (perempuan) "dihijrahkan" ke daerah Leuwi Catang, arah gunung Pongkor. Sementara putranya yang pertama ke Lebak Larang arah Pelabuhan Ratu, terus ke Pasir jeungjing-BojongcisonoTegallumbu-Talaga-SirnaresmiCiganas-Ciptarasa-Ciptagelar, Sukabumi. Jadi kasepuhan yang tersebar di beberapa daerah di Sukabumi tersebut awalnya dari Urug. ${ }^{29}$

\footnotetext{
${ }^{25}$ Daerah Panyaungan, Parung Sapi, Cipatat dan Urug masih di kabupaten Bogor, sementara daerah Sajra, Seuni dan Lebak Binong sudah masuk ke Provinsi Banten sekarang.

${ }^{26}$ Wawancara Pribadi dengan Abah Ukat (ketua Adat Urug Lebak), Bogor, 22 April 2012.

${ }^{27}$ Wawancara Pribadi dengan Abah Ukat (ketua Adat Urug Lebak), Bogor, 28 April 2012.

${ }^{28}$ Gambar atau Photo dilampirkan.

${ }^{29}$ Wawancara Pribadi dengan Abah Ukat (ketua Adat Urug Lebak), Bogor, 28 April 2012.
} 
Putra ketiga tadi yang mendapat amanat untuk mewarisi Kampung Adat Urug mempunyai tujuh orang anak disebarkan ke beberapa daerah, yang paling jauh berada di Pasir Eurih, Banten. yang paling tua di Cipatat kolot mendapat amanat sekedar menjaga makam Prabu Siliwangi. Yang menerima amanat di Kampung Urug kembali putra yang terakhir. Beliau kemudian punya anak lima dari dua istri. Dari istri yang tua tiga, sementara dari istri yang muda dua. Anak pertama dari istri yang pertama tadi menjadi cikal bakal ketua adat Urug Tonggoh dan Tengah. Anak kedua dari istri pertama, perempuan. Anak ketiga, lakilaki yang kembali mendapat amanat untuk di Kampung Adat Urug(Lebak). Dua anak dari istri yang muda, pertama laki-laki, kedua perempuan di Cidogèr, Sukajaya, Bogor. ${ }^{30}$

Mengenai identitas Prabu Siliwangi, menurut Abah Ukat hanya ada satu Prabu Siliwangi namun namanya banyak. di satu tempat satu nama, ketika dia muncul dan menghilang itu. Jayadewata namanya sewaktu kecil, nama lainnya Manahrasa, "setiap orang punya manah, setiap orang punya rasa, (hati dan perasaan)."disebut Prabu itu artinya orang tua (sepuh) yang tinggi ilmu pengetahuannya, wangi itu harum, silih berarti sifat (saling) harus silih asih, silih asah dan silih asuh. Karena itu, keharuman Pajajaran Bogor sampai sekarang tidak hilang. Sedangkan makam Prabu Siliwangi menurut Abah Ukat ada di Cipatat kolot atau Cipatat Girang, kecamatan Sukajaya kabupaten Bogor hanya tempat pulangnya di sini. $^{31}$

Dari keterangan tersebut, pertama megenai nama kampung Adat Urug memang pada awalnya bernama

\footnotetext{
${ }^{30}$ Wawancara Pribadi dengan Abah Ukat (ketua Adat Urug Lebak), Bogor, 28 April 2012.

${ }^{31}$ Wawancara Pribadi dengan Abah Ukat (ketua Adat Urug Lebak), Bogor, 28 April 2012.
}

Kampung Guru, Guru dalam terminologi bahasa Sunda berarti digugu dan ditru, harus bisa menjadi panutan. Dalam konteks ini, adalah si pendiri kampung (Prabu Siliwangi) yang jauh sebelumnya sudah menetapkan sebuah lahan untuk perkampungan yang menjadi panutan tersebut. Hanya di sini terdapat dua perbedaan mengenai maksud dibaliknya kata Guru itu, pertama sebagai kamuflase (penyamaran) agar perkampungan subur tersebut tidak diketahui oleh pihak yang tidak diinginkan. Kedua menurut Abah Ukat, nama Guru dibalik menjadi Urug, karena dikhawatirkan generasi-generasi berikutnya hanya sekedar menyandang makna Guru tetapi tidak bisa mengamalkan nilai-nilai dibalik kata guru tersebut. ${ }^{32}$

Mengenai tokoh Prabu Siliwangi yang dipercaya sebagai pendiri Kampung Urug, penulis lebih condong pada penjelasan dari Abah Ukat, karena terdapat kesamaan antara nama-nama Prabu Siliwangi yang lain yang disebutkan oleh Abah Ukat dengan yang tertulis di buku-buku akademik sejarah, seperti Jayadewata, Manah Rasa dan gelarnya Sribaduga Maharaja, nama-nama tersebut ditulis dalam beberapa buku akademik sejarah mengenai sejarah Tanah Sunda atau sejarah Jawa Barat yang keterangannya sebagian dikutip dari Prasasti Batu Tulis, Carita Ratu Pakuan atau Naskah Wangsakerta, sementara itu Abah Ukat sekolah tingkat dasar kelas dua pun tidak selesai, dari mana beliau bisa tahu.

\section{Kehidupan Masyarakat Kampung Adat Urug}

Jumalah penduduk Kampung Adat Urug tercatat 5.125 jiwa dengan penduduk laki-laki berjumlah 2.875

\footnotetext{
${ }^{32}$ Wawancara Pribadi dengan Abah Ukat (ketua Adat Urug Lebak), Bogor, 28 April 2012.
} 
jiwa dan penduduk perempuannya 2.250 jiwa. Sama seperti masyarakat sunda lainnya, warga Kampung Adat Urug juga mengenal pemerintahan formal. Ketua Adat di sini hanya pemimpin adat atau informal. Warga Urug terbagi ke dalam 4 RW dan 15 RT. Untuk masalah pendidikan formal bisa dikatakan, tingkat pendidikan warga Urug masuk dalam kategori rendah. Sampai bulan Maret-Juni 2012 tercatat hanya 384 murid Sekolah Dasar, tingkat SLTP 235 orang, tingkat SLTA 30 orang dan dua orang untuk tingkat perguruan tinggi. ${ }^{33}$

Dari segi politik sedikit sekali yang bisa dicatat, dalam PEMILU misalnya, seperti penuturan Abah Ukat "Sudah menjadi adat di sini dalam masalah pemilu misalnya mengenai Partai Politik itu PDI (Partai Demokrasi Indonesia), karena dari dulu dari leluhur kami juga PDI, Abah sempat bertanya masalah ini kepada warga yang sudah mempunyai hak pilih, apakah mau diteruskan atau dimusnahkan? (maksud dimusnahkan di sini mereka sama sekali tidak akan ambil bagian dalam PEMILU atau GOLPUT). Jawaban mereka, diteruskan, karena sudah menjadi adat dari dahulunya". 34

Seperti masyarakat Sunda lainnya warga Urug untuk sistem kekerabatan tidak membedakan garis keturunan baik dari pihak ayah maupun pihak ibu karena bagaimanapun juga mereka adalah bagian dari komunitas besar Masyarakat Sunda dan pada dasarnya mereka yakin berasal dari sumber yang sama. Yang menarik sikap gotong royong dan saling membantu masih terasa. Penulis menyaksikan sendiri, ketika ada salah satu warga

\footnotetext{
${ }^{33}$ Monografi Kampung Adat Urug, Desa Kiarapandak, Kecamatan Sukajaya, kabupaten Bogor, Maret 2012 dan daftar siswa SDN Kiarapandak 02 tahun ajaran 2011/2012 pertanggal April 2012.

${ }^{34}$ Wawancara Pribadi dengan Abah Ukat (Ketua Adat Urug Lebak), Bogor, 28 April 2012.
}

yang akan mengadakan hajat pernikahan, walaupun tidak diwajibkan, tapi warga yang lainnya dengan sukarela dan kesadaran sendiri menyumbang makanan berupa kuehkueh dan sebagainya. Hal ini karena mereka patuh pada ucapan leluhur mereka, kudu paheuyeuk-heuyeuk leungeun paantai-antai tangan, nulung ka nu butuh, nalang ka nu susah (maksudanya harus saling membantu, bekerjasama atau saling menolong)

Menurut penuturan bapak Adé (SEKDES Kiarapandak) "dahulu ketika zaman belum seramai dan secanggih seperti sekarang, dalam adat pernikahan itu, calon mempelai pria syaratnya harus bisa nutus (menganyam daun kiray untuk dijadikan atap rumah), sedangkan calon mempelai wanitanya harus bisa nutu, (menumbuk padi di lesung)." 35

\section{Pertanian Sebagai Jalan Kehidupan}

Seperti masyarakat Kasepuahan lainnya, masyarakat Kampung Adat Urug mayoritas sebagai petani dalam mencukupi kebutuhan hidupnya seharihari. Tercatat 4.320 orang $^{36}$ bekerja sebagai petani, kepemilikan lahan pertanian di Kampung Adat Urug adalah perorangan atau milik masingmasing, penulis kutip di sini beberapa petikan wawancara dengan para ketua adat mengenai pertanian yang menjadi mayoritas kegiatan warganya, termasuk sejarah dan latar belakangnya.

Dari penuturan Abah Ukat "Yang dilaksanakan di sini ada beberapa kegiatan salah satunya dalam pertanian sebagai jalan kehidupan masyarakat di sini khususnya menanam padi wajibnya setahun sekali, Abah menanam padi itu satu tahun sekali.

\footnotetext{
${ }^{35}$ Wawancara Pribadi dengan Bapa Ade Eka Komara (SEKDES Kirapandak), Bogor, 21 April 2012.

${ }^{36}$ Monografi Kampung Adat Urug, Desa Kiarapandak, Kecamatan Sukajaya kabupaten Bogor, Maret 2012.
} 
Bahan pokok pagi sore, padi. prabu siliwangi sebagai leluhur kami menguatkan kegiatannya pada pertanian, senjatanya juga kujang, itu alat pertanian. ${ }^{37}$ Maka, kegiatan yang digarap oleh abah tidak lewat dari pertanian, sebab tani itu tidak bisa berbohong, yang dilaksanakan dalam urusan padi yang sangat dimulyakan sebagai tanda penghormatan karena sebenarnya apa padi itu? secara syareat, kita tidak akan punya tenaga jika tidak ada padi. Diantaranya acara syukuran sebanyak lima kali sebagai ketuanya abah".

Berhubungan dengan pertanian (padi), di Kampung Adat Urug dikenal cerita tentang Dewi Sri, yang disebut Nyai Sri, Nyai berarti perempuan. Jenisnya merah, putih, hitam, hijau dan kuning gelarnya di pajajaran Bogor oleh Prabu siliwangi kiriman dari Sorga Maniloka dari Kahyangan Jagad Suralaya dari para Dewa. Wujud awalnya berupa telur yang dijaga oleh Dewa Anta selama 40 hari sampai menetasnya. Awalnya selama 39 hari tidak menetas, Dewa Anta memanggil Prabu Siliwangi, oleh Prabu Siliwangi dicipta menjadi seorang manusia, perempuan, dikenal dengan Dewi Sri, umur sekian tahun meninggal tanpa dikubur digeletakkan begitu saja. Dari kedua mata Dewi Sri keluar tanaman berupa padi, tiga ikat dan dua ikat, jadi ada lima jenis seperti yang sudah ditulis di atas tadi, akhirnya yang hijau dan yang kuning menyatu ke dalam Raga Prabu Siliwangi. jenis yang merah, putih dan hitam gelar ke dunia menjadi padi seperti yang kita kenal sekarang. Kelima jenis Padi itu Tadinya diturunkan di Pajajaran Bogor,

\footnotetext{
${ }^{37}$ Keterangan mengenai Kujang sebagai alat pertanian terdapat dalam naskah Sanghyang Siksakandang Karesian. Lihat Saleh Danasasmita, dkk., Sewaka Darma, Sanghyang Siksakandang Karesian, Amanat Galunggung: Transkripsi dan Terjemahan (Bandung: proyek pengkajian dan penelitian kebudayaan Sunda (Sundanologi), 1987), h. 84 dan 108.
}

berhubung Prabu Siliwangi menghilang dan menuju Kampung Adat Urug, jadi segala-galanya dibawa oleh Prabu siliwangi termasuk bibit padi yang lima itu. Syareatnya yang ditanam hanya tiga, yang merah, putih dan hitam, hakekatnya bibit yang lima tadi disimpan di suhunan (atap) rumah adat urug Lebak yang berjumlah lima, satu atap satu warna. Tiga yang gelar tadi, hakekatnya Gedong Gedè (Rumah Adat Urug Lebak), Gedong Luhur atau Paniisan (tempat berteduh), berupa bangunan panggung tinggi tapi tidak terlalu besar dan GedongLeutik bangunan sangat kecil. ${ }^{38}$

"jika tahu pada badan Sri maka tahu pada badan kita, karena Sri setiap hari kita makan, menyumbang dan mengisi badan kita salah satunya menjadi tenaga yang kita gunakan dalam aktifitas sehari-hari. Jadi Sri jangan di terlantarkan harus disayang, maka bahagia karena banyak dan jangan mengeluh karena sedikit, ketika sedikit asalkan cukup dan manfaat bagi kita, ketika banyak jangan disia-siakan, coba bagaimana kalau kita sehari saja tidak bertemu nasi?"39

Dalam berbagai upacara yang berhubungan dengan pekerjaan menanam padi pada setiap tahap siklus pertanian, menurut keyakinan para petani, benih tanaman serta tanah tempat tertanam itu, memiliki jiwa, agar dapat menghasilkan buah yang menjadi sumber kehidupan, maka harus diperlakukan dengan baik. Pekerjaan menanam padi harus dilakukan menurut aturan-aturan yang pelik sekali, mulai dari penggunaan azimat dan doa-doa. apabila padinya sudah tua lalau dipotong dengan sebuah ketam yang terselindung dalam tangan, supaya tidak

\footnotetext{
${ }^{38}$ Wawancara Pribadi dengan Abah Ukat (ketua Adat Urug Lebak), Bogor, 15, 22 dan 28 April 2012.

${ }^{39}$ Wawancara Pribadi dengan Abah Amat (ketua Adat urug Tengah), Bogor, 16 dan 19 April 2012.
} 
menakutkan dan menghalau jiwa dermawan daripada padi itu. ${ }^{40} \mathrm{Hal}$ ini sangat sesuai dengan prinsip siklus pertanian di Kampung Adat Urug, ketam sebagai alat tadisional memanen padi masih digunkan, di daerah Sunda pada umumnya ketam disebut ètèm (ani-ani).

Yang menarik di sini, warga Kampung Adat Urug tidak menjual hasil pertanian mereka, padi sebagai bahan pokok pangan itu hanya untuk keperluan sehari-hari. Selain bertani waraga Urug tercatat 1.279 orang $^{41}$ sebagai pedagang, dalam hal ini mereka yang menjadi pedagang eceran Ikan air laut di daerah Leuwiliang. Sementara lainnya kebanyakkan sebagai penambang emas Liar di Gunung Pongkor, dan mayoritas adalah anak muda.

\section{Kearifan Lokal Kampung Adat Urug}

\section{Konsep Ngaji Diri}

Ngaji diri (memahami diri sendiri atau mawas diri) adalah suatu ajaran dasar pembinaan moral yang di dalamnya tercermin pula pengertian koreksi diri. Ajaran tersebut dikembangkan di kalangan warga Kasepuhan sebagai upaya melawan sifat buruk dalam diri manusia, seperti iri dengki. Selain itu ajaran ini bertujuan untuk mencapai kondisi yang tertib, selaras, aman dan tentram dalam diri manusia pada kehidupan sosial di dunia sebagai bekal untuk kehidupan di akherat nanti. ${ }^{42}$

\footnotetext{
${ }^{40}$ Sartono Kartodirjo, ed., Elite Dalam Perspektif Sejarah, h. 15.

${ }^{41}$ Monografi Kampung Adat Urug, Desa Kiarapandak, Kecamatan Sukajaya kabupaten Bogor, Maret 2012.

${ }^{42}$ Kusnaka Adimihardja, Kasepuhan yang Tumbuh di Atas yang Luruh: Pengelolaan Lingkungan Secara Tradisional di Kawasa Gunung Halimun Jawa Barat (Bandung:
}

Untuk mencapai keselarasan tersebut, manusia harus mengetahui apa yang diperbolehkan dan apa yang dilarang dalam kehidupan sehari-hari, maka ucapan dan tindakan harus seirama. Hal ini tercermin dalam ungkapan warga kasepuhan, "mipit kudu amit ngala kudu mènta, nganjuk kudu nawur nginjem kudu mulangkeun, leungit kudu daèk ngaganti, sontakna kudu daèk nambal (mengambil dan memetik harus izin, mempunyai hutang harus dibayar, meminjam harus dikembalikan, hilang harus mengganti, rusak harus memperbaiki)" atau dalam ungkapan "nganggo kudu suci, dahar kudu halal kalawan ucap kudu sabenerna, mupakat kudu sarèrèa, ngahulu ka hukum, nyanghunjar ka nagara (berpakaian harus bersih, makan harus yang halal, mufakat harus bersama-sama, patuh pada hukum dan berlindung pada negara)". ${ }^{43}$

Di Kampung Adat Urug, ngaji diri ini disebut pula Tapa Manusa ${ }^{44}$, memahami siapa sebenarnya jati diri manusia, hakekat manusia. Seperti penuturan Abah Ukat, Manusia diwajibkan untuk ngaji diri agar mengetahui dirinya sendiri, manusia yang sudah mengenal dirinya sendiri akan dekat dengan Gustinya (Tuhan), maka hidupnya tidak akan sombong dan angkuh, "samèmèh nyiwit batur, nyiwit heula diri sorangan (sebelum mencubit orang lain, mencubit dulu diri sendiri)", jika tidak ingin disakiti maka jangan menyakiti orang lain, ingin dihormati, maka dia akan menghormati orang lain terlebih dahulu. Kemudian

Tarsito, 1992), h. 37. Lihat pula Arthur S Nalan, Sanghyang Raja Uyeg: Dari Sakral Ke Profan (Bandung: Humaniora Utama Press, 2000), h. 15-16.

${ }^{43}$ Kusnaka Adimihardja, Kasepuhan yang Tumbuh di Atas yang Luruh, h. 37. Arthur S Nalan, Sanghyang Raja Uyeg: Dari Sakral Ke Profan, h. 15-16.

${ }^{44}$ Wawancara Pribadi dengan Mang Ujang (warga dan kerabat Ketua Adat Kampung Urug), Bogor, 16 April 2012. 
untuk apa dia diciptakan, tiada lain untuk patuh pada peraturan, taat pada perintah, dan melaksanakan apa yang dikehendaki Tuhannya.

Selanjutnya yang mana sebenarnya yang disebut manusia? Yaitu yang tidak iri dengki, jail dan menyakiti, tidak menipu dan berbohong, ulah ngaguar rusiah batur (tidak membicarakan atau membongkar keburukkan orang lain). Manusia adalah yang mempunyai sifat benar dan jujur, welas asih dan tolong menolong, paheuyeuk-heuyeuk leungeun pantaiantai tangan, (saling membantu). Manusia harus bisa nulung ka nu butuh, nalang ka nu susah, nyaangan ka nu poèkkeun, ngahudangkeun ka nu labuh, ngajait ka nu raheut (menolong kepada yang membutuhkan dan kesusahan, memberi penerangan kepada yang kegelapan, membangunkan yang terjatuh dan mengobati yang sedang terluka). ${ }^{45}$ Dalam tapa manusa, manusia harus bisa seperti meri ngojay di leuwi, sireum leumpang dina batu (angsa berenang di telaga, semut berjalan di atas batu). Angsa berenang di telaga dan semut berjalan di atas batu tidak meninggalkan bekas atau jejak, bersih, maka manusia dalam hidupnya harus bersih dari sifat-sifat tercela. ${ }^{46}$

Konsep tapa manusa atau ngaji diri juga mengharuskan manusia untuk bersikap adil, tergambar dalam ungkapan ulah nyiwit $\mathrm{ka}$ nu hideung ulah montèng ka nu konèng, ulah ngadèngdèk topi (jangan mencubit yang hitam, jangan berpaling ke yang kuning, jangan miring tutup kepala) artinya, harus adil dan bijak, tidak berat sebelah, tidak membedakan perlakuan terhadap orang-orang kelas menengahatas dan kalangan bawah. misalnya dalam menerima tamu harus disamakan

\footnotetext{
${ }^{45}$ Wawancara Pribadi dengan Abah Ukat (Ketua Adat Urug Lebak), Bogor, 15 April 2012.

${ }^{46}$ Wawancara Pribadi dengan Mang Ujang (warga dan kerabat Ketua Adat), Bogor, 16 April 2012.
}

ketika menerima tamu antara cacah dan mènak (masyarakat biasa dan pejabat misalnya). Sebenarnya sama dengan sifat Rahman-Rahim, adil untuk semua mahluk.

Tidak hanya itu, dalam ngaji diri manusia harus pintar, luas pengetahuan dan wawasannya, diwajibkan mencari ilmu seperti dalam ungkapan elmu tungtut dunya siar, nu awon kudu disinglar (ilmu itu bisa diperoleh dari mana saja, hanya yang tidak baik harus dibuang atau disingkirkan). Tapa manusa atau ngaji diri ini juga mengingatkan manusia agar tidak lupa kepada dua perkara, Tuhan menciptakan segala sesuatunya berpasangan, ayah dan ibu, laki-laki dan perempuan, siang dan malam, terang dan gelap, hakekat dan sareat dan lain sebagainya, tujuannya adalah keseimbangan, maka manusia dalam hidupnya harus seimbang, tidak berlebihan tapi tidak kekurangan.

Masyarakat Kampung Adat Urug yang menjadikan pertanian sebagai jalan kehidupan, dalam ajaran ngaji diri untuk keseimbangan dunia dan akherat mengenal istilah tunda geusan alaeun dan teundeun geusan sampeureun. Tunda geusan alauen (ditunda sebentar untuk dipetik hasilnya dalam waktu deukat) dalam hal ini kegiatan mereka bertani, hasilnya bisa dinikmti di dunia sekarang, seperti padi, palawija dan sebagainya, tapi tetap harus ingat mipit kudu amit ngala kudu menta (memetik dan mengambil harus izin kepada yang punya), semua orang jika menanam pohon pisang misalnya, tidak dengan gula, lalu siapa yang memberi rasa manis pada buah pisang ketika masak? Maka harus sadar dan ingat pada siapa yang memberi manisnya agar selalu bersyukur, karena manusia sebenarnya tidak daya dan upaya, hanya Allah yang kuasa. Maka di sini harus hati-hati jangan berlawanan dengan aturan, baik yang ada dalam kitab Al-Qur'an maupun di adat sebagai ilmu papaku. 
Kata teundeun geusan sampeureun (disimpan untuk dijemput kemudian hari), yaitu mengerjakan ibadah yang lima waktu dan ibadah-ibadah lainnya, itu untuk disimpan, ditabung sekarang dan diambil hasilnya ketika menuju alam keabadian, akherat. ${ }^{47}$

Konsep ngaji diri sebagai koreksi diri sendiri dijelaskan oleh Abah Amat yang selalu dihubungkan dengan Sri (padi). "Jika paham dengan Sri maka akan paham dengan badan sendiri, karena Sri setiap hari kita makan, menyumbang dan mengisi badan kita salah satunya menjadi tenaga yang kita gunakan dalam aktifitas sehari-hari. Jadi Sri jangan diterlantarkan, harus disayang maka bahagia karena banyak dan jangan mengeluh karena sedikit, ketika sedikit asalkan cukup dan manfaat bagi kita, ketika banyak jangan disia-siakan, bagaimana seandainya sehari saja tidak bertemu nasi"? Menurut kepercayaan masyarakat Kampung Adat Urug tiga jenis padi yaitu padi merah, putih dan hitam pada hakekatnya menjadi bagian dari diri manusia, padi merah menjadi darah, padi putih menjadi sumsum dan padi hitam menjadi rambut-rambut yang ada pada tubuh manusia. ${ }^{48}$

Selanjutnya Abah Amat menambahkan, dalam tubuh manusia terdapat hitung-hitungan yaitu, dua puluh, delapan dan sembilan. Yang duapuluh, sepuluh di atas sepuluh di bawah, adalah jari jemari di tangan dan kaki manusia, yang delapan adalah empat ruas tangan dan empat ruas kaki dan yang sembilan adalah dua mata, dua lubang telinga, dua lubang hidung, mulut dan dua lubang pembuangan dalam tubuh manusia. Maknanya itu semua pada hakekatnya adalah pemberian dari Tuhan, titipan dari Tuhan, anugrah yang Dia berikan.

\footnotetext{
${ }^{47}$ Wawancara Pribadi dengan Abah Ukat (Ketaua Adat Urug Lebak), Bogor, 15 April 2012.

${ }^{48}$ Wawancara Pribadi Dengan Abah Amat (Ketua Adat Urug Tengah), Bogor, 19 April 2012.
}

Manusia bernapas sama sekali tidak direncanakan, tidak pula berencana akan mengedipkan kelopak mata setiap waktunya, Maka harus sadar siapa yang membuat udara keluar masuk dalam hidung kita dan siapa yang mengedipkan kelopak mata kita. Jadi manusia harus menggunakan dengan baik setiap anugrah-Nya, jangan digunakan untuk hal yang negatif karena nanti akan dimintai pertanggungjawabannya". ${ }^{49}$

Selain ajaran moral dan etika yang sudah dijelaskan di atas, konsep ngaji diri atau tapa manusa juga mengajarkan untuk menjaga kehormatan kaum perempuan. Bisa diketahui dari ungkapan ulah ngahakan barang atah (jangan memakan barang mentah), barang mentah di sini ternyata konotasi untuk perempuan yang belum melalui akad nikah itu jangan dicampuri. $^{50}$ Bahkan menurut Abah Ukat, lahan pertanian setelah proses penen, baru bisa digarap kembali jika sudah melewati waktu 40 hari, sama halnya dengan Istri yang sudah melahirkan, tidak boleh dicampuri sebelum melewati waktu 40 hari. ${ }^{51}$

Dalam naskah Sunda lama, Sanghyang Siksakandang Karesian ada larangan agar jangan mendekati Estri Larangan (perempuan yang sudah dipinang, tunangan atau istri orang lain) dan Rara Hulanjar (janda-perawan) untuk menghindari fitnah dan menjaga kesucian diri. Ingeutkeun na Siksakandang Karesian, deung iseuskeun na haloan, ulah ngeringkeun estri larangan sakalih, rara hulanjar sakalih, bisi keuna $k u$ haloan panghawanan. Maka nguni ngarowang tangan, sapanglungguhann di catang,

\footnotetext{
${ }^{49}$ Wawancara Pribadi dengan Abah Amat (Ketua Adat Urug Tengah), Bogor, 19 April 2012.

${ }^{50}$ Wawancara Pribadi dengan Mang Ujang (warga dan Kerabat Ketua Adat Urug), Bogor, 16 April 2012.

${ }^{51}$ Wawancara Pribadi dengan Abah Ukat (Ketua Adat Urug Lebak), Bogor, 28 April 2012.
} 
di balè, patutunggalan, haloan si panglungguhan ngara(n)na. Patanjeurtanjeur di pipir, di buruan patutunggalan, haloan si pana taran ngara(n)na. (ingat-ingat dalam siksakandang karesian dan perhatikan dalam godaan. Jangan berjalan mengiringi semua wanita larangan, semua rara hulanjar, agar tidak terkena godaan di perjalanan. Demikian pula memegang tangannya, duduk bersama di bangku, di balai berdua saja. Disebut godaan ditempat duduk. Berdiri di belakang rumah atau di halaman berdua saja. Disebut godaan ditempat berdiri namanya). ${ }^{52}$

Pada Masyarakat Kampung Adat Urug, ajaran ngaji diri atau tapa manusa tersebut diuraikan lagi sehingga melahirkan beberapa larangan atau anjuran yang disebut talèk (aturan hidup) baik untuk pribadinya sendiri maupun untuk hidup bermasyarakat. Di bawah ini, penulis jelaskan adat istiadat atau nilai-nilai budaya yang menjadi kearifan lokal di Kampung Adat Urug dalam kehidupan sosial masyarakatnya.

\section{Larangan Untuk Mengambil Yang Bukan Haknya}

Larangan untuk mengambil yang bukan haknya ini tergambar dalam ungkapan Mipit kudu amit, Ngala kudu mènta $^{53}$ artinya mengambil atau memetik itu harus meminta izin kepada yang mempuyainya, dengan kata lain jangan mencuri. Para ketua Adat di Kampung Urug dan warga umumnya juga mengatakan hal yang sama, bahkan ada istilah jika kita melewati kebun seseorang, tangan itu harus

\footnotetext{
${ }^{52}$ Saleh Danasasmita, dkk., Sewaka Darma, Sanghyang Siksakandang karesian, Amanat Galuggung: Transkripsi dan Terjemahan (Bandung: Proyek Penelitian dan Pengkajian Kebudayaan Sunda, 1987), h. 78 dan 101.

${ }^{53}$ Wawancara Pribadi dengan Abah Ukat (Ketua Adat Urug Lebak), Bogor, 15 April 2012.
}

dikepalkan $^{54}$ artinya jangan memetik buah-buahan di kebun orang, jika kita memang mau, ya harus meminta izin kepada si Pemilik kebun. Di lingkungan Kampung Adat atau Kasepuhan, hal semacam inilah yang disebut pamali, sebenarnya sama dengan apa yang dikatakan haram dalam agama Islam ${ }^{55}$, maksud dan tujuannya sama hanya berbeda istilah saja.

Di tambahkan oleh Bapa Ade Eka Komara bahwa "Ungkapan mipit kudu amit ngala kudu menta menganjurkan untuk hidup tertib, jangan sembarangan, kenapa? Bisi aya tunggul kalarung catang karumpak (untuk menghindari terambilnya hak orang lain oleh Kita)." 56

Dalam naskah Sunda lama, Sanghyang Siksakandang Karesian, terdapat juga larangan mencuri. Nyangcarutkeun sakalih ma ngara(n)na: mipit mo amit, ngala mo mènta, ngajuput mo sadu. Maka nguni tu: tunumpu, maling, ngetal, ngabègal; sing sawatek cekap carut, ya nyangcarutkeun sakalih ngara(n)a. (yang disebut menghianati orang lain adalah memetik milik orang tanpa izin, mengambil tanpa meminta, memungut tanpa memberi tahu. Demikian pula merampas, mencuri, merampok, menodong; segala macam perbuatan hianat ya, menghianati orang lain namanya. Mencuri termasuk dalam Panca Gati, yaitu lima penyakit hati yang harus dihindari. ${ }^{57}$

\footnotetext{
${ }^{54}$ Wawancara Pribadi dengan Mang Ujang (warga dan kerabat Ketua Adat Urug), Bogor, 16 April 2012.

${ }^{55}$ Wawancara Pribadi dengan Mang Misnan (warga Kampung Adat Urug), Bogor, 18 April 2012. Wawancara Pribadi dengan Abah Amat (Ketua Adat Urug Tengah), Bogor, 17 April 2012.

${ }^{56}$ Wawancara Pribadi dengan Bapa Ade Eka komara (Sekretaris Desa Kiarapandak), Bogor, 21 April 2012.

${ }^{57}$ Saleh Danasasmita, dkk., Sewaka Darma, Sanghyang Siksa Kandang Karesian, Amanat Galunggung: Transkripsi dan Terjemahan, h. 76 dan 98.
} 
Pada Masrakat Kampung Adat Urug, ungkapan Mipit kudu amit ngala kudu mènta tidak hanya berarti secara harfiah saja, yaitu larangan jangan mencuri. Dibalik arti itu terdapat makna yang dalam menganai rasa syukur mereka terhadap Yang Maha Kuasa. Pada hakekatnya bumi beserta seluruh isinya ini adalah milik Tuhan yang dianugrahkan kepada segenap mahluknya, tanaman padi yang menjadi bahan pokok mereka dan tanaman lainnya, tumbuh di atas bumi-Nya atas izin-Nya pula, maka ketika akan mengambil atau memanen hasil dari tanaman itu, harus memohon izin dulu kepada Pemilik bumi.

Ungkapan rasa syukur ini mereka wujudkan dalam acara adat Seren Taun, syukuran atas hasil panen ${ }^{58}$ dalam acara adat ini diadakan selamatan dan doa, berterimakasih kepada Sang Pencipta atas hasil panen tahun ini dan semoga panen pada tahun-tahun berikutnya juga bagus.

\section{Murah Bacot Murah Congcot}

Murah Bacot artinya senang menyapa orang lain dengan ramah dan sopan santun, sedangkan murah congcot, baik hati suka memberi atau berbagi makanan, congcot atau aseupan adalah alat tradisional untuk menanak nasi berbentuk kerucut yang terbuat dari anyaman berbahan baku bambu, terkadang digunakan sebagai alat mengukus. Congcot di sini melambangkan makanan.

Murah bacot murah congcot secara harfiah adalah sikap ramah tamah yang harus ditunjukkan seorang pribumi kepada tamu. Murah congcot berarti si pribumi harus menjamu tamu dengan hidangan yang ada, jika hidangan sudah disuguhkan maka harus

\footnotetext{
${ }^{58}$ Mengenai acara Seren Taun dijelaskan pada bab-IV sebagai salah satu media pelestarian adat.
}

murah bacot, si pribumi harus menawari tamu untuk mencicipinya, karena jika tidak ditawari, kemungkinan si tamu agak sungkan padahal sebenarnya mau. Dan perlu diingat satu hal, murah bacot murah congcot ini harus dilakukan dengan ikhlas, jangan mengeluh jika makanan yang sudah disuguhkan itu habis oleh tamu, karena hal semacam itu merusak amal ibadah kita. ${ }^{59}$ Anjuran ini sepertinya lahir karena Kampung Adat Urug sering dikunjungi tamu baik pada hari-hari biasa maupun pada upacara adat, dan untuk bahan panganan sebagai hidangan sang tamu, warga Kampung Adat Urug selalu tersedia, karena mereka belum pernah kekurangan bahan pokok makanan terutama beras.

Ternyata murah bacot murah congcot tidak hanya sikap ramah tamah kepada tamu, murah dalam perkataan tidak hanya dikhususkan kepada tamu, tapi umum untuk semua orang, maksudnya kita harus mau menyapa orang lain terlebih dahulu, bertutur kata dengan baik dan sopan, permisi jika melewati orang lain di jalan karena dengan begitu kita pasti akur dan akrab dengan orang lain, begitupun sebaliknya jika kita adigung (sombong), tidak akan ada yang mau akrab denga kita. Contoh jika kita bertandang ke kampung orang terus kita mau menyapa dengan ramah dan sopan pasti disenangi diajak mampir, sekadar air minum pasti ada. ${ }^{60}$

Murah bacot itu sama juga halnya jika kita tidak mengerti atau tidak tahu, harus bertanya dan tahu tempat bertanya. Masalah pertanian harus bertanya kepada petani, ke ahli-ahli pertanian, masalah penyakit ke dokter, itu juga dinamakan murah bacot.

\footnotetext{
${ }^{59}$ Wawancara Pribadi dengan Abah Amat (Ketua Adat Urug Tengah) dan Abah Kayod (Ketua Adat Urug Tonggoh), Bogor, 19 April 2012.

${ }^{60}$ Wawancara Pribadi dengan Mang Ujang (Warga dan Kerabat Ketua Adat), Bogor 16 April 2012.
} 
Murah congcot juga tidak hanya suka memberi makanan kepada tamu, tapi kepada siapa saja jika kita punya harus berbagi, terutama kepada mereka yang sangat membutuhkan. ${ }^{61}$

Dalam naskah Sanghyang Siksakandang tertulis Tadaga carita angsa, Gajendra carita banem, matsyanem carita sagarem, puspanem carita bangbarem (telaga dikisahkan oleh angsa, hutan dikisahkan oleh gajah, ikan mengisahkan samudra dan bunga dikisahkan oleh kumbang), maknanya jika kita ingin bertanya suatu hal maka tanyalah pada ahlinya. ${ }^{62}$

\section{Guru Ratu Wong Atuo Karo}

Guru Ratu Wong Atua karo, wajib menghormati guru, ratu (pemerintah) dan kedua orang tua, terutama kedua orang tua, "itu adalah pakem sepuh. Jadi Orang tua itu merupakan Guru dan sekaligus Ratu, kenapa kedua orang tua ditulis di belakang, bukan berati kedua orang tua menjadi yang terakhir dihormat diantara ketiganya, justru harus paling pertama dan utama dihormat, karena tadi, kedua orang tua itu berperan atau mempunyai fungsi sebagai Guru dan Ratu". Begitulah penuturan dari Bapak Ade Eka komara yang tidak jauh berbeda maknanya dengan yang disampaikan oleh ketiga orang ketua adat mengenai penghormatan kepada orang tua.

Selanjutnya beliau menuturkan, "dalam ruang lingkup terkecil, rumah tangga atau keluarga, Orang tua itu harus bisa menjadi guru bagi anak cucunya misal, dengan memberikan contoh yang baik dengan ucapan, sikap dan perilaku. Yang disebut menjadi ratu di sini harus bisa memimpin keluarga,

\footnotetext{
${ }^{61}$ Wawancara Pribadi dengan Bapak Ade Eka Komara (SEKDES Kiarapandak), Bogor 21 April 2012.

${ }^{62}$ Saleh Danasasmita, dkk., Sewaka Darma, Sanghyang Siksa Kandang Karesian, Amanat Galunggung: Transkripsi dan Terjemahan, h. 106-107
}

jangan sampai keluarga berantakan karena orang tuanya tidak bisa memimpin, nah di sinilah penghormatan kepada kedua orang tua sangat diwajibkan. Nah sekarang ratu atau pemerintah, tentunya ratu yang harus diikuti itu yang bagaimana? Jangan apabila ratu yang tidak baik, djolim kepada rakyatnya". ${ }^{63}$

"Ada peribahasa, Indung kudu dipunjung, bapa kudu dipuja, munjung ulah sok ka gunung, muja ulah sok ka sagara (jangan menyembah pada gunung dan lautan tapi "sembahlah" ibu bapa/kedua orang tua), karena indung tunggul rahayu bapa tangkal darajat, Kalau kita ingin punya kerahayuan, keselamatan hidup dunia dan aherat, mintalah do'a kepada ibu, jangan ke mana-mana dan benar-benar ibu kita itu harus dihormat. Apabila ingin punya derajat kehidupan, jangan pergi ke mana-mana tapi datangi yang jadi bapa, mintalah do'anya, benar-benar hormati bapa apabila kita ingin punya derajat kehidupan, karena kuncinya ada pada orang tua, sebab ridhonya Allah SWT ada pada orang tua kita". ${ }^{6}$

Kalimat Guru Ratu wong Atua karo ini bisa diartikan secara terpisah atau dalam satu kesatuan yang merupakan simbol, seperti yang sudah dijelaskan tadi, terutama kita harus menghormati kedua orang tua. Orang tua mempunyai fungsi sebagai guru harus bisa mendidik, karena orang tua itu pendidik pertama dan utama, karena pengajaran yang didapat anak-anak di sekolah itu bisa dihitung hanya beberapa jam saja, sementara di lingkungan keluarga si anak jauh lebih banyak mendapat didikan dan nasehat dari orang tua, maka dari itu orang tua disebut pendidik pertama dan utama

\footnotetext{
${ }^{63}$ Wawancara Pribadi dengan Bapak Ade Eka Komara (SEKDES Kiarapndak), Bogor, 21 April 2012.

${ }^{64}$ Wawancara Pribadi dengan Bapak Ade Eka Komara (SEKDES Kiarapandak), Bogor, 21 April 2012.
} 
yang harus mempunyai sifat tutwuri handayani, bisa membimbing dan mengawasi dari belakang agar perilaku anak tidak nyolowèdor (menyimpang), tidak melanggar aturan agama, negara dan adat. Ratu adalah pimpinan, orang tua terutama ayah harus bisa memimpin keluarga, karena seorang pemimpin itu akan dimintai pertanggungjawabannya di akherat, yang namanya pemimpin di sini harus mempunyai kebijakkan dan kesejahteraan. Sejahterakan kehidupan anak-anaknya oleh ilmu baik di sekolahkan maupun dipesantrenkan.

Sementara jika diartikan secara terpisah, dengan logika yang sederhana saja, bagaimana pun juga jika kita melawan kapada kedua orang tua, maka akan durhaka, melawan kepada guru, ilmu tidak akan bermanfaat, dan melawan kepada Ratu, pemerintah yang baik artinya orang yang sedang mempunyai kekuasaan atau jabatan, maka akan mendapat kesusahan.

Bahkan dalam naskah Sanghynag Siksakandang Karesian, "manusia sejati" adalah dia yang menyempatkan untuk mengunjungi kedua orang tuanya sesibuk apapun. aya twah urang ma eureunan. Hanteu twah urang ma ungang ambu bapa. Kalingana janma ngaranna. Ya sinangguh paramarta wisesa. Nya sang purna sarira, nya wit ning hayu, ya puhun ning bener (Bila sedang sibuk tundalah sementara, apalagi bila sedang tidak ada pekerjaan, untuk menjenguk ibu bapak, itulah yang disebut manusia sejati, yang disebut keutamaan tertinggi, berpribadi sempurna, benih kebajikkan dan pohon kebenaran). ${ }^{65}$

\section{Hidup Sederhana dan Mandiri}

Hidup sederhana di sini maksudnya jangan berlebihan dalam

65 Saleh Danasasmita, dkk., Sewaka Darma, Sanghyang Siksa Kandang Karesian, Amanat Galunggung: Transkripsi dan Terjemahan, $\mathrm{h}$. 81 dan 105 segala sesuatu. Misalnya makan hanya sekedar penghilang lapar, minum sekedar menghilangkan haus dan tidur hanya untuk menghilangkan kantuk, jangan berlebihan, dan jangan pula kekuarangan asal berkecukupan.

makan hanya penghilang lapar tujuannya untuk menghindari sifat rakus, ketika manusia sudah memiliki sifat rakus, tamak dan serakah, ngarawu ku siku (mengambil seusatu bukan lagi dengan ukuran kepalan tangan tapi dengan siku) yang pada akhirnya hak orang lain terambil. Kemudian tidur hanya penghilang kantuk, manusia itu hidup punya kewajiban baik masalah dunia maupun aherat, jangan siang dan malam tidur, siang untuk bekerja mencari nafkah untuk keluarga, malam untuk istirahat, segala seuatu juga harus pada waktu dan tempatnya. Juga bisa menimbulkan penyakit jika tidur dan makan berlebihan. ${ }^{66}$

Dalam naskah Sanghyang Siksakandang Karesian, tertulis Jaga rang hèès tamba tun(n)duh, nginum tamba hanaang, nyatu tamba ponyo, ulah urang kajon(ng)jonan. Yatnakeun maring ku hanteu. (Hendaklah kita tidur sekedar penghilang kantuk, minum sekedar penghilang haus, makan sekedar penghilang lapar, janganlah kita berlebih-lebihan. Ingatlah bila suatu saat kita tidak memiliki apaapa. ${ }^{67}$ Pada masyarakat Kasepuhan hidup berkecukupan ini, tidak berlebihan dan tidak kekurangan, disebut Siger tengah (ditengah-tengah), diungkapkan dengan kalimat ulah hareup teuing bisi tijongklok, ulah tukang teuing bisi tijengkang (jangan

\footnotetext{
${ }^{66}$ Wawancara pribadi dengan Bapak Ade Eka (Sekretaris Desa Kiarapandak), Bogor, 21 April 2012.

${ }^{67}$ Saleh Danasasmita, dkk., Sewaka Darma, Sanghyang Siksa Kandang Karesian, Amanat Galunggung: Transkripsi dan Terjemahan, $\mathrm{h}$. 82 dan 105.
} 
terlalu depan, nanti tersungkur, jangan terlalu belakang, nanti terlentang). ${ }^{68}$

Disamping cukup, hidup juga harus mandiri, dituliskan pula dalam naskah Sanghyang Siksakandang Karesian, ini pangimbuh ning twah pakeun mo tiwas kalamanghurip, pakeun wastu di imah di maneh. Emet, imeut, rajeun, leukeun, pakapredana, morogol-rogol, purusa ning sa, widagda, hapitan, karawaleya, cangcingan, langsitan. Jaga rang ngajadikeun gaga-sawah, tihap ulah sangsara. Jaga rang nyieun kebon, tihap ulah ngu(n)deur ka huma beet sakalih, ka huma lega sakalih. Hamo ma beunang urang laku sadu. Cocooan ulah tihap meuli mulah tihap nukeur. Pakarang ulah tuhap nginjeum (ini pelengkap perbuatan agar tidak gagal dalam hidup agar rumah tangga kita penuh berkah, yaitu cermat, teliti, rajin, tekun, cukup sandang, bersemangat, berperibadi pahlawan, bijaksana, berani berkorban, dermawan, cekatan dan terampil. Bila kita membuat sawah untuk sekedar tidak sengsara, bila kita membuat kebun, untuk sekedar tidak mengambil sayur-sayuran di ladang kecil dan besar milik orang lain, sebab tak akan dapat memintanya, memelihara ternak untuk sekedar tidak membeli atau menukar, memiliki perkakas untuk sekedar tidak meminjam). ${ }^{69}$

Hidup mandiri seperti itulah yang penulis saksikan pada kehidupan Masyarakat kampung Adat Urug. Mereka memiliki sawah yang luas $\left(6.200 \mathrm{Ha}^{70}\right.$ bahkan sampai masuk ke Desa lain, tapi dari hasil panen itu sama sekali tidak dijual, panen satu tahun

\footnotetext{
${ }^{68}$ Kusnaka Adimihardja, Kasepuhan yang Tumbuh di Atas yang Luruh: Pengelolaan Lingkungan Secara Tradisional di Kawasa Gunung Halimun Jawa Barat, h. 41

69 Saleh Danasasmita, dkk., Sewaka Darma, Sanghyang Siksa Kandang Karesian, Amanat Galunggung: Transkripsi dan Terjemahan, $\mathrm{h}$. 81 dan 105

${ }^{70}$ Sudah dijelaskan pada bab II.
}

sekali cukup untuk persediaan, minimal dua tahun. Air melimpah, tidak kekeringan pada saat musim kemarau, karena mereka merawat alam, menjaga hutan larangan, yang dijadikan kayu bakar hanya batang pohon yang sudah kering atau mati. lauk pauk mereka sediakan sendiri, seperti telur, ayam, itik, kecuali ikan asin mereka membeli begitu juga dengan pakaian.

\section{Pengendalian Alat Tubuh}

Salah satu jalur pamali di kampung Adat Urug yaitu mengendalikan alat tubuh. Alat tubuh atau indera kita jangan sampai disalahgunakan untuk hal-hal yang tidak baik. Indra kitapun sudah tau haknya masing-masing Sekarang misalnya hidung hanya bisa mencium, sukanya wewangian, telinga hanya bisa mendengar, mata hanya bisa melihat, makan syariatnya hanya dilakukan oleh mulut, lidah yang merasakan, tapi mata, telinga dan hidung tidak pernah protes ingin merasakan makanan yang di makan oleh mulut, karena mereka sadar akan haknya masing-masing. Begitupun manusia harus konsisten dengan tugasnya masing-masing. Jadi pamali itu banyak jalurnya bila kita melanggar pasti badan yang merasakan akibatnya ada pribahasa nafsu kasasarnya lampah badan anu katempuhan (bila kita terbawa nafsu, maka badan yang menanggung akibatnya). Bicara jangan sembarangan, melangkah jangan salah. Kata orang tua jaman dulu, lebok mah ulah ditincak (jalan berlubang jangan dilewati), nanti celaka. ${ }^{71}$

Seperti yang sudah dijelaskan di awal, semua alat tubuh manusia itu hakekatnya pemberian Sang Pencipta, maka harus dimanfaatkan untuk hal-hal baik saja karena akan dimintai pertanggungjawabannya kelak. Terutama yang harus dipelihara itu lisan. Ada ungkapan biwir teu diwengku

\footnotetext{
${ }^{71}$ Wawancara Pribadi dengan Abah Amat (Ketua Adat Urug Tengah), Bogor, 19 April 2012.
} 
(bibir tidak dijaga), lètah teu tulangan (lidah tidak bertulang). Manusia harus berhati-hati menggunakanya karena bisa menjadi bibit rujit (pangkal permasalahan), maka bibir dan lidah yang tidak bertulang itu harus diwengku (dijaga) oleh hati ${ }^{72}$

Mengenai pengendalian alat Tubuh ini ditambahkan pula oleh Mang Ujang, warga Kampung Adat Urug. "amanat dari orang tua mewanti-wanti kita agar berhati-hati menggunakan alat-alat tubuh Tangan jangan dipakai sembarangan apalagi menyakiti orag lain, jangankan memukul manusia, memukul hewan dan tumbuhan pun tidak dibenarkan Pokoknya Perbuatan kita jangan sampai merugikan orang lain". 73

Begitu pun Bapak Ade Eka Komara menambahkan, "mata ulah dipake ngadeuleu lamun lain deuleunnana, ceuli ulah dipake ngadèngè lamun lain dèngèunnana, yang artinya kita harus bisa menjaga, memelihara semua indera yang ada pada tubuh kita jangan sampai digunakan pada hal-hal yang negatif karena memang bukan tempatnya, harus hati-hati dalam ucapan dan perbuatan, hidung jangan dipake sembarangan"

Sementara itu dalam Naskah Sanghyang Siksakandang juga terdapat keterangan mengenai pengendalian alat tubuh ini, diantaranya tertulis mata ulah barang deuleu mo ma nu sieup dideuleu kenana dora bancana, sangkan urang nети mala nu lunas papa naraka, hengan lamun kapahayu ma sinengguh utama ning deuleu (Mata jangan sembarang melihat yang tidak layak dipandang karena menjadi pintu

\footnotetext{
${ }^{72}$ Wawancara Pribadi dengan Abah Amat (Ketua Adat Urug Tengah), Bogor, 19 April 2012.

${ }^{73}$ Wawancara Pribadi dengan Mang Ujang (warga kampung Adat Urug), Bogor, 16 April 2012.

${ }^{74}$ Wawancara Pribadi dengan Bapa Ade Eka Komara (Sekretaris Dsesa Kiarapandak), Bogor, 21 April 2012.
}

bencana penyebab kita mendapat celaka di dasar kenistaan neraka, namun jika mata terpelihara kita akan mendapat keutamaan dalam penglihatan). Begitupun seterusnya dituliskan mengenai alat tubuh yang lain termasuk alat kelamin. $^{75}$

Demikianlah nilai-nilai budaya atau kearifan lokal yang menjadi adat istiadat di kampung Adat Urug. Sesungguhnya, konsep ajaran ngaji diri atau tapa manusa beserta bagianbagiannya bukan milik khusus warga kampung Adat atau Kasepuhan saja, tetapi merupakan pandangan hidup orang Sunda umumnya pada masa lampau (Naskah Sanghyang Siksakandang Karesian), ${ }^{76}$ hanya saja pada masyarakat kasepuhan adat istiadat tersebut masih banyak yang bertahan. Berbeda dengan masyarakat sunda di luar kasepuhan, walaupun ada yang mengetahui dan mengamalkannya itu hanya beberapa kalangan saja, lagipula agak sulit untuk mengetahui seseorang mengamalkan adat istiadat semacam itu karena sifatnya yang abstrak dan tergantung pribadi masingmasing.

Dalam masyarakat Sunda, ada Istilah Cageur, bener, pinter (sehat jasmani rohani, benar dan pintar) atau silih asih, silih asah, silih asuh (saling mengasihi, mengembangkan dan menjaga) yang tidak hanya diamalkan untuk diri sendiri, tapi untuk alam dan lingkungan sekitarnya. Orang Sunda memandang lingkungan hidupnya, baik lingkungan masyarakat maupun lingkungan alam, bukanlah sebagai segala sesuatu yang harus ditundukkan, melainkan harus dihormati, diakrabi dan dirawat. ${ }^{77}$ Hal ini karena orang

\footnotetext{
${ }^{75}$ Saleh Danasasmita, dkk., Sewaka Darma, Sanghyang Siksa Kandang Karesian, Amanat Galunggung: Transkripsi dan Terjemahan, h. 94-96 dan 73 -74.

${ }^{76}$ Kusnaka Adimihardja, Kasepuhan yang Tumbuh di Atas yang Luruh, h. 41

${ }^{77}$ Suwarsih Warnaen, dkk., Pandangan Hidup Orang Sunda Seperti Tercermin Dalam Tradisi
} 
Sunda hidup di alam tropis yang begitu subur melimpah dengan segala keperluan hidup, sehingga mereka merasa hanya bagian kecil dari lingkungan alam tersebut dan menemukan kelemahan dirinya ${ }^{78}$ dihadapan alam yang luarbiasa dan tentu saja dihadapan Pemilik alam sekaligus Pemilik diri mereka sendiri, sehingga lahirlah kearifan lokal seperti ngaji diri atau tapa manusa sebagai manifestasi hubungan mereka dengan alam sekitar yang harus harmonis (Kosmologis). Nampaknya cageur, bener, pinter adalah induk atau wadah dari semua aturan hidup masyarakat Sunda.

\section{PRANATA SOSIAL KAMPUNG ADAT URUG}

\section{Sesepuh (Ketua Adat) sebagai Elit Masyarakat}

Dalam kamus umum Basa Sunda, Sesepuh berasal dari kata Sepuh yang artinya kolot (tua) mengacu pada umur seseorang. Sesepuh berarti orang yang dituakan dan diajènan (dihormati). ${ }^{79}$ Pada setiap Kampung Adat di Indonesia, Sesepuh hanya memiliki wewenang dalam urusan adat (kepemimpinan informal) karena bagaimana pun juga Kampung Adat atau kasepuhan itu masuk dalam ruang lingkup pemerintahan Desa, kecamatan, kabupaten atau kota, provinsi dan tentu saja Negara Kesatuan Republik Indonesia, jadi selain hukum adat juga harus mengikuti hukum negara. Sesuai dengan pernyataan Abah Ukat (Ketua

Lisan dan Sastra Sunda: Konsistensi dan Dinamika (Bandung: Proyek Penelitian dan Pengkajian Kebudayaan Sunda, Departemen Pendidikan dan Kebudayaan, 1987), h. 245.

${ }^{78}$ H. Sulyana WH, dkk., Siliwangi Adalah Rakyat Jawa Barat, Rakyat Jawa Barat Adalah Siliwangi (Bandung: Badan Pembina Citra (BPC) Siliwangi, 2006), h. 146.

${ }^{79}$ Panitia Kamus Lembaga Basa dan Sastra Sunda, Kamus Umum Basa Sunda (Bandung: Tarate Bandung, 1975), h. 470.
Adat Urug Lebak), bahwa beliau sangat mengakui dan menghormati pemerintahan NKRI dengan kalimat buhun disuhun sara dibawa (aturanaturan adat, negara dan agama harus berjalan beriringan).

Warga kasepuhan atau ada juga yang menyebutnya kesatuan dalam bahasa Indonesia menunjukkan suatu kelompok sosial yang memiliki keseragaman dalam pola perilaku kehidupan sosio-budayanya. Hal ini tampak antara lain dalam setiap kelompok pemukiman terdapat Sesepuh yang disebut juga Kokolot sebagai tali pengikat kesatuan.

Para sesepuh atau kokolot inilah yang memimpin berbagai upacara adat yang berlaku di kalangan warga kasepuhan selain itu mereka juga berfungsi sebagai tempat meminta nasehat dan petunjuk serta tempat pananggeuhan (bernaung) di kalangan warga kasepuhan yang bermukim di sekitar kampung itu. istilah kasepuhan berasal dari kata sepuh yang berawalan $k a$ - dan berakhiran -an. Sepuh adalah sinonim dari kata kolot (bahasa Sunda) yang berarti tua dalam bahasa Indonesia. Sebutan kasepuhan menunjukkan sebuah sistem kepemimpinan dari suatu komunitas atau kelompok sosial di mana semua aktifitas semua anggotanya berasaskan pada adat kebiasaan orang tua (sepuh atau kolot). Kasepuahan berarti adat kebiasaan tua atau adat kebiasaan nenek moyang. hal ini tampak dalam tatacara kehidupan mereka yang masih secara ketat menjalankan apa yang mereka sebut tatali paranti karuhun. ${ }^{80}$

Sesepuh mempunyai kekuasaan dalam menentukan adat istiadat warga masyarakatnya. Ia dituakan oleh masyrakatnya karena ia keturunan pendiri desa sekaligus dianggap memiliki wibawa magis yang selalu

\footnotetext{
${ }^{80}$ Kusnaka Aidmiharja, Kasepuhan: yang Tumbuh Di atas yang Luruh (Bandung: Tarsito, 1992), h. 4.
} 
memelihara warga masyarakatnya dengan ketentuan-ketentuan adat istiadat yang berasal dari nenek moyang mereka. Seorang sesepuh besar peranannya dalam partisipasi masyarakat bagi usaha-usaha pembangunan desa, gotong royong, upacara-pacara pertanian, siklus hidup, membantu melancarkan roda pemerintahan desa. Meskipun kepemimpinan tradisional di daerah ini hanya dalam hal adat istiadat, rupanya sebelum pengaruh Islam, meliputi pula semua aspek kehidupan, termasuk religi. ${ }^{81}$

Di Kampung Adat Urug, elit Masyarakat yang dimaksud dalam kajian ini adalah Ketua adat yang berjumlah tiga orang; Urug Lebak (Bawah) sebagai pusat dipimpin oleh Abah Ukat, Urug Tengah (Tengah) dipimpin oleh Abah Amat dan Urug Tonggoh (atas) dipimpin oleh Abah Kayod. ${ }^{82}$ Ketiga ketua adat ini mempunyai hubungan kekerabatan yang dekat, dari hasil pengamatan penulis, pembagian kepemimpinan ini hanya untuk mempermudah jalannya adat di sana, contoh dalam acara Seren Taun, karena Kampung Adat Urug yang begitu luas dan warganya yang begitu banyak tidak akan tertampung semua di satu rumah adat, misalnya pada saat prosesi ngariung(berkumpul), ${ }^{83}$ dan

\footnotetext{
${ }^{81}$ Edi Suhardi Ekadjati, ed., Masyarakat Sunda dan Kebudayaannya (Jakarta: P T Girimukti Pasaka, 1984), h. 45.

${ }^{82}$ Pengamatan penulis selama di lokasi penelitian pada tanggal 15-29 April 2012.

${ }^{83} \mathrm{Ngariung}$ artinya berkumpul. Dalam salah satu upacara adat misalnya Seren Taun, (syukuran pesta panen) ngariung menjadi salah satu manual acara di mana warga semua berkumpul di rumah adat untuk berdo'a bermunajat pada Yang Maha Kuasa dan bersyukur atas hasil panen tahun itu dan semoga panen tahun-tahun berikutnya juga memuaskan. Setelah pembacaan do'a selesai maka makanan yang sudah disiapkan sebelumnya yang juga sekaligus dido'akn akan dibagikan kepada warga yang hadir baik dari kampung Adat Urug sendiri maupun dari luar. Wawancara Pribadi
}

juga tidak hanya warga Urug yang datang pada saat acara adat ini. Penggunaan nama Lebak, Tengah dan Tonggoh hanya mengacu pada lokasi rumah ketua adat. jika dilihat dari bentang alam Kampung Adat Urug yang berada di lembah, rumah adat Lebak yang ditempati oleh Abah Ukat berada di bawah sebagai pusat di mana rumah warga yang saling berdekatan "berkiblat" pada rumah adat tersebut.

Regenerasi atau pergantian ketua adat di Kampung Adat Urug khususnya di Urug Lebak sebagai Pancer (Pusat) berdasarkan wangsit ${ }^{84}$ atau amanat yang akan diterima oleh ketua adat yang sedang menjabat, yang dipercaya berasal dari leluhur mereka untuk menentukan siapa yang akan menjadi Ketua Adat berikutnya. ${ }^{85}$ Para ketua adat ini biasa disebut Abah Kolot, Abah saja atau kokolot. Abah adalah salah satu sebutan atau panggilan kepada ayah, Di samping sebutan kepada ayah, Abah digunakan pula sebagai sebutan khas oleh masyarakat Sunda kepada orang-orang tertentu yang seakan-akan berhak atau pantas memakainya. ${ }^{86}$ Sebutan Abah juga biasanya ditujukan kepada orang yang berkarisma atau berwibawa meskipun usianya belum begitu tua, misalnya dalam hal ini ketua adat Urug Lebak, Abah Ukat.

\section{Upaya Sesepuh Dalam Menjaga Adat Istiadat}

dengan Abah Ukat (Ketua Adat Urug Lebak), Bogor, 28 April 2012.

${ }^{84}$ Wangsit adalah petunjuk gaib yang diperoleh atau diterima pada saat tafakur, nyepi atau meditasi. Lihat Kusnaka Adimiharja, Kasepuhan yang Tumbuh Di atas yang Luruh: pengelolaan Lingkunagan secara Tradisional di kawasan gunung Halimun Jawa Barat, h. 197.

${ }^{85}$ Wawancara Pribadi dengan Abah Ukat (ketua adat Urug Lebak), Bogor, 15 April 2012.

${ }^{86}$ Ajip Rosidi, dkk., Ensiklopedi Sunda: Manusia dan Budaya termasuk Cirebon dan Betawi (Jakarta: Pustaka Jaya, 2000), h. 3. 
Seperti sudah dijelaskan pada bab-bab sebelumnya, adat istiadat yang bertahan di Kampung Adat Urug yang dijadikan fokus pembahasan yaitu wujud absrak dari sebuah kebudayaan berupa nilai-nilai kehidupan mengenai tata kelakuan yang diwariskan secara lisan antar genearsi yang sudah dijelaskan pada bab 3, hal ini dalam lingkungan warga Kasepuhan terangkum dalam istilah ngaji diri (memahami diri sendiri) Upaya-upaya yang dilakukan oleh para Ketua Adat di sini untuk sementara terbatas pada pemberian nasehat atau amanat yang tidak bosan-bosanya dilakukan secara berulang-ulang, baik itu pada saat upacara adat ataupun pada hari-hari biasa secara pribadi antara Ketua Adat dan warga yang sengaja datang, seperti yang dituturkan oleh Abah Amat.

"Diam di daerah kasepuhan itu ibaratnya seperti ngasuh, terutama ketua adat harus bisa ngasuh warganya agar jangan celaka, bagi mereka yang sudah diwejang ( dinasehati) tapi masih melanggar maka tunggu akibatnya, Abah hanya sekedar memberi tahu, menasehati diikuti syukur tidak pun tidak apa-apa karena pada dasarnya untuk kebaikkan mereka juga. Seperti yang sudah tadi Abah jelaskan, salah satu tugas Abah sebagai ketua adat itu memberikan nasehat kepada warga mengenai pamali, (larangan atau cegahan) biasanya dalam acara Seren Taun misalnya Abah akan kembali memberikan wejangan itu, karena sebenarnya semua warga harus memakai peraturan kolot baheula (orang tua zaman dahulu), tidak sedikit memang yang melanggar dan ketika mereka mendapat akibatnya, mereka kembali ke Abah untuk minta sare'at bantuan". 87

Juga ditegaskan oleh Abah Kayod "Abah juga sering memberikan wejangan kepada warga secara lisan

\footnotetext{
${ }^{87}$ Wawancara Pribadi dengan Abah Amat (Ketua
} Adat Urug Tengah), Bogor, 17 April 2012. karena sudah turun temurun. Apabila orang tua berkata jangan ya jangan, harus diikuti, kalau dilanggar suka ada akibatnya, penyakit. Nah pada waktuwaktu tertentu Abah pasti memberikan amanat dari orang tua zaman dahulu seperti dalam acara sedekah Rowah dan Mulud karena warga berkumpul pada acara itu, ini amanat dari orang tua jangan di langgar, harus bisa akur dengan sesama, mufakat, harus bisa saling memaafkan, harus murah bacot murah congcot, menghormati yang lebih tua, harus mau menyapa dan bertanya jika tidak tahu." 88 Hal ini juga dikuatkan oleh keterangan dai $\mathrm{Pa}$ Sekdes“ untuk menjaga adat tersebut Ketua Adat dan para orang tua memberikan nasehat bahkan ngaweruh (memberikan wejangan) terutama dalam hal ahlak talajag (moral dan etika). ${ }^{89}$

Abah Ukat juga memberikan keterangan yang sama dengan Abah Amat dan Abah Kayod tentang usaha mereka dalam menjaga adat istiadat "Nah nanti di acara Seren Pataunan yang di bulan Muharam, Abah paling minta waktu selama seperempat jam untuk menceritakan sejarah dan memberikan wejangan. yang belum diceritakan oleh oleh kakek, ayah dan paman Abah, Abah ceritakan dalam acara ini. Banyak yang heran ketika Abah bercerita menurut mereka Abah mendapat sumber dari mana apakah dari manusia atau dari "Hakekat", bisa sampai sejauh itu sedangkan umurnya belum begitu tua si Abah, seharusnya mereka yang lebih sepuh harus lebih tau. Semuanya diam".

"Tahun 2007 atau 2008 yang lalu ketika Abah bercerita masyarakat Urug banyak yang pangling sama

\footnotetext{
${ }^{88}$ Wawancara Pribadi dengan Abah Kayod (Ketua Adat Urug Tonggoh), Bogor, 19 April 2012.

${ }^{89}$ Wawancara Pribadi dengan Bapak Ade Eka Komara (SEKDES Kiarapandak), Bogor, 21 April 2012.
} 
Abah, ada yang mendengar suara Abah berbeda dari biasanya, ada yang melihat wujud Abah beda. Sampai ada yang melihat, Abah jadi mempunyai janggut sampai sepanjang pangkuan. Tidak ada yang kenal sama Abah, emak nangis wujud Abah hilang. Padahal Abah merasa seperti biasa-biasa saja".

"Minimal selama dua hari dua malam Abah melayani tamu banyak sampai ribuan dengan profesi dan statusnya masing-masing tanpa henti, menghadap satu persatu biasanya habis Subuh mulai, waktu Isa Abah baru buang air kecil, tidak makan tidak minum nah di situ Abah memberikan nasehat sesuai dengan yang diperlukan tamu Abah masing-masing. Abah tidak pernah mengada-ngada cerita. Kalau acara yang Seren Taun itu kebanyakan hanya kaum tani sedangkan Seren Pataunan nah itu dari mana-mana, bahkan luar Jawa pokonya dari manamana". 90

Jadi seperti sudah dijelaskan sebelumnya, sejauh ini hasil pengamatan penulis untuk sementara usaha para Ketua Adat Di Kampung Urug dalam melestarikan adat istiadat itu terbatas pada pemberian nasehat secara lisan baik pribadi, antara Ketua adat dengan seorang warga yang sengaja datang atau dalam suatu Upacara adat, disampaikan kembali amanat dari leluhur mereka oleh Ketua Adat itu kepada semua warga yang hadir, metodenya seperti ceramah.

Di bawah ini adalah uraian dari lima upacara adat yang dilaksanakan dalam satu tahun dan dijadikan media atau sarana oleh Ketua adat dalam menyampaikan amanat dari leluhur mereka dalam rangka tetap menjaga kebertahanan adat istiadat. Dalam kegiatan seperti inilah diantaranya Ketua Adat bekerja sama dengan pemerintah Daerah untuk keberlangsungan acara tersebut seperti

\footnotetext{
${ }^{90}$ Wawancara Pribadi dengan Abah Ukat (Ketua Adat Urug Lebak), Bogor, 28 April 2012.
}

bantuan biaya dan lain sebagainya. Menurut Abah Ukat, lima acara tersebut dilaksanakan tidak sebatas kegiatan saja, tapi mengandung hikmah yang harus dijalankan oleh Warga Urug karena ada pokok atau sebab-sebab penting kenapa upacara tersebut harus dilaksanakan..$^{91}$

\section{Muludan}

Upacara pertama memperingati kelahiran Nabi Muhammad SAW tanggal 12 Mulud (Rabi'ul Awal) yang biasa disebut Muludan. Dalam acara ini Ketua Adat bersama warga khusus mengrim do'a untuk Nabi Muhammad karena Sudah berjasa membawa agama Islam. Biasanya dalam acara tersebut dihidangkan makanan-makanan khas daerah dan olahan lauk pauk yang akan dibagikan kepada warga setelah dido'akan.

Alasan diadakannya acara ini menurut Abah Ukat, Nabi Muhammad pada saat berusia 25 tahun dipanggil oleh Yang Maha Kuasa, akan diberi Kitab Rasul dan Tasauf kemudian harus mengajarkan rukun Islam yang lima perkara di Negara Mekah. Nabi Muhammad patuh, taat dan melaksanakan Kehendak Yang Maha Kuasa, maka selama mengajarkan rukun Islam di negara Mekah tersebut dan seterusnya, Nabi Muhammad akan selalu dikirim "bekal" oleh Yang Maha Kuasa, hakekatnya berupa do'a-do'a dari setiap umat Islam yang melaksanakan acara Muludan tersebut, karena itulah Abah Ukat bersama warga Kampung Adat Urug melaksanakannya sebagai wujud bakti kepada Nabi Muhammad. $^{92}$

\footnotetext{
${ }^{91}$ Wawancara Pribadi Dengan Abah Ukat (Ketua Adat Urug Lebak), Bogor, 28 April 2012.

${ }^{92}$ Wawancara Pribadi dengan Abah Ukat (Ketua adat Urug Lebak), Bogor, 28 April 2012.
} 


\section{Seren Taun}

Upacara kedua disebut Seren Taun (Syukuran hasil panen), dilaksanakan sebagai ungkapan rasa syukur dari para petani di sini yang dipimpin Ketua Adat. Ungkapan rasa syukur, karena ada istilah mipit kudu amit ngala kudu mènta (memetik dan mengambil harus minta izin kepada yang punya), rasa syukur ini ditujukan kepada yang pertama kali telah memberikan bibit pokok dalam masalah pangan kepada manusia, yaitu Yang Maha Kuasa, karen pada hakekatnya bumi tempat tumbuh berbagai macam tanaman yang bermanfaat bagi manusia adalah milik Yang Maha Kuasa, maka ketika akan mengambilnya harus meminta izin kepada yang punya

Rincian kegiatan atau manual acaranya seperti yang dituturkan Abah Ukat berikut "Kegiatan ini dilaksanakan setelah semua warga selesai panen. tahun 2012 yang akan datang ini, acara Seren Taun sudah ditetapkan oleh abah pada tanggal 6 Juni. Acara dimulai dari tanggal 5 Juni, minimal jam 11 Abah meyembelih kerbau. Setelah semua prosesi penyembelihan kerbau sampai dimasak selesai sekitar jam empat sore, Abah mengadakan selametan ${ }^{93}$, ya harus itu untuk kerbau yang dipotong dan untuk yang memotongnya. Dipanjatkan do'a agar pertanian dan petaninya di sini selamat ada dalam keberkahan begitu juga umumnya dengan negara kita semoga subur makmur tidak terkena musibah, pada akhirnya itu umum untuk semua warga dan bangsa."

"Pada malam rabunya istirahat, sampai pada hari rabu, pagi sekitar jam tujuh atau jam delapan pagi Abah bersama warga ziarah ke makam leluhur Abah, untuk pertama Abah ke

\footnotetext{
${ }^{93}$ Acara selametan ini disebut juga ngariung (berkumpul), semua warga berkumpul di rumah adat untuk berdo'a bersama, tentu lengkap dengan hidangan makanan yang sudah disiapkan.
}

makam yang di Gedong Leutik, setelah itu baru masyarakat pun menyebar ziarah ke makam para kerabatnya. Sepulang ziarah Abah selametan lagi sebagai tanda telah ziarah ke makam para leluhur kami Sekitar jam 2 atau jam 3, lama mengaturnya, mempersiapkan hidangan dan sebagainya karena banyak yang datang bukan warga Urug saja. Syukuran Abah mengirim do'a khusus ke ahli kubur keluarga abah umumnya kepada semua petani tidak hanya di Bogor dan pulau Jawa, untuk seluruh Indonesia dan dunia umumnya. Karena itu sudah menjadi tugas Ketua Adat yang ada di Kampung Urug."

"Nah pada hari Rabu malam kamisnya, Abah Selametan lagi setelah ba'da Isa ramai rumah adat penuh dari mana-mana yang datang, selesai selametan baru hiburan dimulai ada beberpa panggung hiburan di sini seperti jaipong, golek dan sebagainya, kelompok hiburan itu kebanyakkan datang sendiri tanpa diundang mendaftarkan diri kepada Abah untuk manggung di sini. Pada hari kamis paginya sekitar jam enam, semua warga masyarakat kumpul satu keluarga minimal membawa satu ekor ayam kemudian disembelih satu persatu oleh ki Amil (sebutan untuk juru sembelih dalam acara tersebut) tempat penyembelihannya harus di sini di dekat rumah adat. Setelah selesai disembelih ayam dimasak oleh masingmasing keluarga minimal ngabakakak (membawa ayam bakar) lalu dibawa kembali ke sini lengkap dengan nasi satu bakul dan olahan lainnya dikumpulkan di sini di rumah adat untuk acara selametan lagi pada hari kamisnya ba'da Dhuhur dan acara selesai. Yang diminta atau dipanjatkan do'a untuk keberkahan dan keselamatan dalam masalah pertanian kepada yang Maha Kuasa, nah itu acara Syukuran Seren Taun, lumayan biayanya bengkak 
walaupun dibantu sedikit oleh
pemerintah."

\section{Sedekah Rowah}

Upacara yang ketiga disebut Sedekah Rowah, dilaksanakan pada bulan Rowah (Sya'ban), tanggal 12. Pagi hari masyarakat membawa ayam minimal satu keluarga satu ekor, disembelih di halaman rumah adat, setelah selesai dimasak, dibawa lagi ke rumah adat, selamatannya dilaksanakan ba'da Dhuhur. Acara ini dan do'a yang dikirim sebagai wujud bakti kepada Nabi Adam Alaihi Salam karena menjadi induk semua umat manusia. Manusia awalnya di akherat, di dunia itu hanya diumbarakeun (dikembarakan) akan kembali ke akherat yang dibawa hanya amal perbuatan baik ataupun buruk yang akan diterima oleh $\mathrm{Nu}$ Kagungan (Yang Maha Memiliki). Nabi Adam sebagai induk seluruh umat manusia awalnya di akherat dahulu, karena suatu hal ia diturunkan ke bumi. ${ }^{94}$

\section{Sedekah Bumi}

Upacara yang ke empat dinamakan Sedekah Bumi, lewat beberapa bulan setelah selesai bulan Rowah (Sya'ban), Puasa (Ramadhan), Syawal. Acara ini diadakan sebelum menanam padi. Semua warga makan bersama di halaman rumah adat, tapi tidak hanya sebatas foya-foya saja, yang dipanjatkan do'anya sebelum makan bersama tersebut, agar semua warga ketika selama menanam padi mulus rahayu berkah salamet (selamat dan ancar tanpa kendala). Maknanya, Kita Manusia duduk-berdiri dan hidup di Bumi, semua yang kita makan berasal dari Bumi, manusia harus bersyukur kepada Yang memiliki kekuasaan terhadap Bumi. Acara

\footnotetext{
${ }^{94}$ Wawancara Pribadi dengan Abah Ukat (Ketua Adat Urug Lebak), Bogor, 28 April 2012.
}

syukuran Sedekah Bumi ini dalam rangka akan menanam padi, sekali lagi, mipit kudu amit, ngala kudu menta (mengambil dan memetik harus meminta izin kepada yang punya $)^{95}$. "Manusia kebanyakkan hanya ingin enaknya saja, ketika menanam padi ingin subur, bagus padinya sedangkan syukuran kepada yang memiliki Bumi tempat di mana padi itu ditanam tidak." Begitu penuturan Abah Ukat.

\section{Seren Pataunan}

Upacara yang kelima dan terakhir yang disebut dengan Seren Pataunan, di bawah ini penulis kutip petikkan wawancara dengan Abah Ukat "Seren Pataunan dilaksanakan dalam rangka menutup tahun 1432 Hijriah menyambut tahun 1433 Hijriah, semoga yang dilakukan pada tahun baru itu semuanya semoga diselamatkan dijaga dan diraksa (dihindarkan dari bahaya). Warga membawa nasi kuning dengan laukpauknya (daging kerbau) setelah dido;akan (selametan) baru dibagikan kembali. keramaiannya lebih dari Seren Taun, minimal ba'da magrib, sudah ramai, karena bukan abah yang mengundang tapi masyarakat yang datang sendiri".

Seperti dalam Seren Taun, pada upacara Seren Pataunan banyak kelompok hiburan seperti Jaipongan, wayang Golek bahkan OrgenTunggal ingin "manggung" di Kampung Adat Urug, datang sendiri tanpa dibayar. tapi itu tergantung Abah Ukat, tidak semua kelompok hiburan itu bisa diterima karena halaman rumah adat sudah dirapihkan dengan semen dan batu jadi tidak diboleh dibongkar untuk mendirikan panggung hiburan. Masyarakat yang datang dari manamana itu tidak sebatas hanya ingin silaturahmi, ikut syukuran mendapatkan berkat makanan atau menyaksikan

\footnotetext{
${ }^{95}$ Wawancara Pribadi dengan Abah Ukat (Ketua Adat Urug Lebak), Bogor, 28 April 2012.
} 
hiburan, tapi punya tujuan masingmasing yang dilisankan biasanya ingin diselamatkan di tahun baru ini. Pada kesempatan itu Abah Ukat mewejang. ${ }^{96}$ "Abah di sini biasanya meminta waktu 15 menit untuk membuka kembali sejarah dan memberikan wejanganwejangan kepada warga umumnya”.

Demikianlah, seperti sudah dijelaskan sebelumnya, melalui lima upacara adat di ataslah, nilai-nilai adat yang sudah turun temurun itu dilestarikan dengan cara dilisankan oleh Ketua Adat kepada warga umumnya (ceramah). Selain itu, ketua Adat Kampung Urug juga menjalin kerjasama dengan Pemerintah terutama dengan Dinas Kebudayaan dan Pariwisata baik Kota Bogor maupun Provinsi Jawa Barat, hingga pada tahun 2010 kampung Adat Urug ditetapkan sebagai Cagar Budaya dan setiap tahun dianggarkan dana untuk kelangsungan upacara adat tersebut. Hal ini dilakukan Oleh Abah Ukat sesuai dengan amanat dari ayahnya, "hirup kudu subur ku dulur beunghar ku baraya (hidup harus subur dan kaya oleh Saudara). Ada dua saudara kita, yaitu Ki Ustad (Ulama) dan Pemerintah, dekatilah mereka".

\section{Penutup}

Uraian-uraian di muka telah menjelaskan tentang kebertahanan adat istiadat atau bisa juga disebut kearifan lokal di Kampung Adat Urug, Desa Kiarapandak, Kecamatan Sukajaya Kabupaten Bogor Jawa Barat. Ada beberpa temuan yang menarik di lapangan terkait dengan aktifitas elit masyarakatnya. adalah:

Beberapa Kesimpulan itu

1. Studi ini memperlihatkan korelasi positif antara adat istiadat di Kampung Adat

\footnotetext{
${ }^{96}$ Wawancara Pribadi dengan Abah Ukat (Ketua Adat Urug Lebak), Bogor, 28 April 2008.
}

Urug dengan peran elit masyarakatnya. Temuan data-data lapangan mendukung kesimpulan tersebut, dengan demikian fakta lapangan melemahkan teori Ajip Rosidi.

2. Kepatuhan dan ketaatan warga terhadap tradisi dan adat istiadat setempat sebagai pedoman bermasyarakat sangat terkait dengan kewibawaan elit masyarakatnya yang terlihat dalam perilaku kehidupan sehari-hari.

\section{Rekomendasi}

Penelitian ini melihat ada beberapa hal yang barangkali bagus untuk diteruskan atau menjadi studi lanjutan, antara lain:

1. Perlu dikaji lebih dalam mengenai upaya elit masyarakat pada wilayah lain terutama kreatifitas mereka yang memang dibutuhkan untuk menjaga kebartahanan adat istiadat.

2. Perkembangan zaman adalah sebuah keniscayaan yang tidak bisa dihindari sehingga membawa perubahan pada nilai-nilai adat yang bersifat instrumental akan tetapi tidak pada nilai-nilai yang fundamental. Dalam konteks inilah diperlukan wawasan kreatifitas elit masyarakat. ${ }^{97}$

3. Peran aktif Pemerintah Provinsi Jawa Barat khususnya, sangat penting dan diperlukan dalam pelestarian budaya daerah,

\footnotetext{
${ }^{97}$ Deliar Noer, Bunga Rampai Dari Negeri Kanguru: Kumpulan Karangan (Jakarta: Panji Masyarakat, 1981), h. 244-245.
} 
terutama melalui Dinas kebudayaan dan Pariwisata. Harus ada anggaran khusus yang memadai secara periodik untuk membantu keberlangsungan tradisi di daerah, mislanya bantuan dana untuk acara adat.

\section{Kepustakaan}

Adimihardja, Kusnaka. Kasepuhan yang Tumbuh di Atas yang Luruh: Penelolaan Lingkungan Secara Tradisional di Kawasan Gunung Halimun Jawa Barat. Bandung: Tarsito, 1992.

Chambert Loir, Henri. "kolofon Melayu." Indonesia and the Malay World, vol.34, no. 100, (November 2006): hal. 1-3.

Danasasmita, Saleh. dkk. Sewaka Darma, Sanghyang Siksakandang Karesian, Amanat Galunggung: Transkripsi dan Terjemahan. Bandung: Proyek Penelitian dan Pengkajian Kebudayaan Sunda (Sundanologi), 1987.

Dudung, Abdurahman. Metodologi Penelitian Sejarah. Jakarta: ArRuzz Media, 2007.

Ekadjati, Edi Suhardi, ed. Masyarakat Sunda dan Kebudayaannya. Jakarta: P.T Girimukti Pasaka, 1984.

Kebudayaan Sunda Jilid 1. Jakarta: Pustaka Jaya, 1995.

Hariyono. Mempelajari Sejarah Secara Efektif. Yogyakarta: Pustaka Jaya, 1995.
Kartodirjo, Sartono, ed. Elite Dalam Perspektif Sejarah. Jakarta: $\quad$ LP3ES, 1981.

Koentjaraningrat. Kebudayaan Mentalitas dan Pembangunan. Jakarta: PT

Gramedia Pustaka Utama, 1974.

kebudayaan di Indonesia.
$\begin{aligned} & \text { Jakarta: Djambatan, } \\ & 1971 .\end{aligned}$

Penelitian Masyarakat. Jakarta:
Gramedia, 1979.

Noer, Deliar. Bunga Rampai Dari Negeri Kanguru: Kumpulan Karangan. Jakarta: Panji Masyarakat, 1981.

Panitia Kamus Lembaga Basa dan Sastra Sunda. Kamus Umum Basa Sunda.

Bandung: Tarate Bandung, 1975.

Rosidi, Ajip. dkk. Ensiklopedi Sunda: Manusia dan Budaya termasuk Cirebon dan Betawi. Jakarta: Pustaka Jaya, 2000. Manusia Sunda,. Jakarta: Inti Idayu Press, 1984.

- Mencari Sosok Manusia Sunda: Sekumpulan Gagasan dan Pikiran. Jakarta: Pustaka Jaya, 2010.

Sanafiah, Faisal, ed. Metodologi Penelitian Kualitatif, Surabaya: Usaha Nasional, 1987. 
Sulyana WH, H. dkk., Siliwangi Adalah Rakyat Jawa Barat, Rakyat Jawa Barat Adalah

Siliwangi. Bandung: Badan Pembina Citra (BPC) Siliwangi, 2006.

Supardan Nalan, Arthur. Sanghyang Raja Uyeg: dari Sakral ke Profan.Bandung: Humaniora Utama Press, 2000 .

Warnaen, Suwarsih. dkk. Pandangan Hidup Orang Sunda Seperti Tercermin Dalam Tradisi Lisan dan Sastra Sunda: Konsistensi dan Dinamika. Bandung: Proyek Penelitian dan Pengkajian Kebudayaan Sunda Departemen Pendidikan dan Kebudayaa, 1987.

WAWANCARA

Wawancara Pribadi dengan Abah Ukat (Ketua adat Kampung Urug Lebak). Bogor, 15, 22 dan 28 April 2012.

Wawancara Pribadi dengan Abah Amat (Ketua adat Kampung Urug Tengah). Bogor, 16, 17, 19 dan 25 April 2012.

Wawancara Pribadi dengan Abah Kayod (ketua adat Kampung Urug Tonggoh). Bogor, 16 dan 19 April 2012.

Wawancara Pribadi dengan Mang Misnan (Warga dan kerabat Ketua Adat Kampung Urug). Bogor, 18 April 2012.

Wawancara Pribadi dengan Mang Ujang (Warga dan kerabat Ketua Adat Kampung Urug). Bogor, 16 April 2012.
Wawancara Pribadi dengan Bapa Ade Eka Komara (Sekretsris Desa Kiarapandak). Bogor, 21 dan 22April2012. 
